Title no. $90-\mathrm{S} 11$

\title{
Bond of Epoxy-Coated Reinforcement: Splices
}

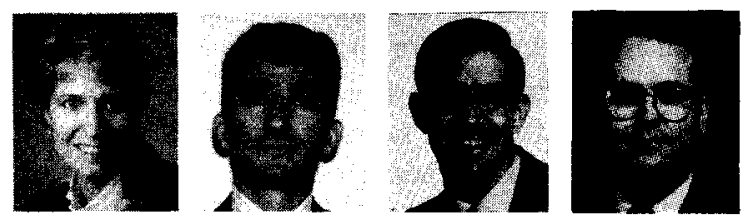

\section{by Cynthia J. Hester, Shahin Salamizavaregh, David Darwin, and Steven L. McCabe}

The effects of epoxy coating and transverse reinforcement on the splice strength of reinforcing bars in concrete are described. A total of 65 beam and slab splice specimens containing No. 6 and No. 8 bars were tested. The average coating thickness ranged from 6 to 11 mils $(0.15$ to $0.28 \mathrm{~mm})$. Three deformation patterns were used. All but one group of specimens contained Class B ACI/Class C AASHTO splices. The results of the current study are analyzed, along with the results of 48 specimens from earlier studies, and used to develop improved development length modification factors for use with epoxy-coated bars. Epoxy coatings are found to reduce splice strength significantly; however, the extent of the reduction is less than that used to select the development length modification factors in the $1989 \mathrm{ACI}$ Building Code and 1989 AASHTO Bridge Specifications. The percentage decrease in splice strength caused by epoxy coating is independent of the degree of confining reinforcement, which provides approximately the same percentage increase in the strength of splices for both coated and uncoated bars. A maximum development length modification factor of 1.35 is applicable for design with epoxy-coated reinforcement. An alternate factor of 1.20 is applicable for epoxy-coated bars with a defined minimum amount of transverse reinforcement if the positive effects of that transverse reinforcement are not already taken into account in the design provisions. Thus, the 1.20 factor is not applicable to the ACI Building Code, but is applicable to the AASHTO Bridge Specifications. This is the second in a series of papers describing research at the University of Kansas on epoxy-coated reinforcement. The research is aimed at gaining a better understanding of the bond of epoxy-coated reinforcement to concrete and developing design procedures that accurately reflect the changes in bond strength caused by epoxy coating.

Keywords: bond (concrete to reinforcement); coatings; deformed reinforcement; epoxy-coated reinforcement; lap connections; pullout tests; reinforcing steels; splicing; structural engineering.

The 1989 AASHTO Bridge Specifications and 1989 ACI Building Code (ACI 318-89) provisions for development length require the use of considerably longer development lengths for epoxy-coated reinforcement than for uncoated steel. The newly adopted development length modification factors are 1.5 for coated bars with less than 3 bar diameters of concrete cover or less than 6 bar diameters of clear spacing between bars, and 1.15 (AASHTO 1989) or 1.2 (ACI 1989) for bars with 3 bar diameters or more of concrete cover and 6 bar diameters or more of clear spacing between bars. Therefore, for a 2-in. (50-mm) cover, No. $6(19-\mathrm{mm})$ and larger coated bars require a 50-percent increase in development length compared to uncoated bars. This requirement impacts both cost and constructability. The new provisions do not account for the effects of transverse reinforcement on the bond strength reduction caused by epoxy coating.

The test results, upon which the 1.5 development length modification factor is based, consist of only 21 specimens, of which 12 contained epoxy-coated reinforcement and none contained transverse steel (Treece and Jirsa 1987, 1989). The reinforcing bar pattern used for the tests is no longer used for epoxy-coated bars because of difficulties in coating application. More recent tests at the University of Kansas using beam-end specimens (Darwin et al. 1990 and Hadje-Ghaffari, Darwin, and McCabe 1991) indicate that epoxy-coated bars with transverse steel have a higher bond strength than epoxy-coated bars without transverse steel. A higher bond strength means that a lower increase in development length may be needed if transverse steel is present.

This paper is the second in a continuing series describing research at the University of Kansas to gain a better understanding of the bond of epoxy-coated reinforcement to concrete and develop design procedures that accurately reflect the changes in bond strength caused by the use of epoxy coating. Earlier research elsewhere (Johnston and Zia 1982, Treece and Jirsa 1987 and 1989, Cleary and Ramirez 1989 and 1991) and at the University of Kansas (Choi et al. 1990; Choi, Darwin, and McCabe 1990; 1991, Darwin et al. 1990; Darwin, McCabe, and Choi 1990; Hadje-Ghaffari, Darwin, and McCabe 1991) has demonstrated that epoxy coatings significantly reduce bond strength. Work at the University of Kansas has shown that the extent of the reduction is less than that reflected by the development length modification factors in the ACI Building Code (1989) and the AASHTO Bridge Specifications (1989). Coating thickness has been shown to have little effect on the amount of bond reduction for No. 6 bars and larger. However, for smaller bars, bond strength reduction appears to increase with coating thickness. For No. 5 (16-mm) bars and larger, the reduction in bond

ACI Structural Journal, V. 90, No. 1, January-February 1993.

Received Oct. 30, 1991, and reviewed under Institute publications policies. Copyright (C) 1993, American Concrete Institute. All rights reserved, including the making of copies unless permission is obtained from the copyright proprietors. Pertinent discussion will be published in the November-December 1993 ACI Structural Joumal if received by July 1, 1993.

*Florida Steel Corporation, personal communication. 
ACI member Cynthia J. Hester is a structural engineer with Theiss Engineers, St. Louis, Missouri. She received her BS degree in architectural engineering in 1989 and her MS degree in civil engineering in 1991 from the University of Kansas.

ACI member Shahin Salamizavaregh is a reseanch engineer with the University of Kansas Center for Research. He received his BS degree in civil engineering in 1989 and his MS degree in civil engineering in 1991 from the University of Kansas.

David Darwin, FACI, is the Deane E. Ackers Professor of Civil Engineering and Director of the Structural Engineering and Materials Laboratory at the University of Kansas. He is a past member of the Board of Direction and the Technical Activities Committee and is Past-President of the Kansas Chapter of ACI. Darwin is Chairman of the Publications Committee and the Concrete Research Council and is a member and past-chairman of ACI Committee 224, Cracking. He is also a member of ACI Committees 408, Bond and Development of Reinforcement; 446, Fracture Mechanics; and Joint ACI-ASCE Committees 445, Shear and Torsion; and 447, Finite Element Analysis of Reinforced Concrete Structures.

ACI member Steven L. McCabe is an Associate Professor of Civil Engineering at the University of Kansas. He is active in research involving reinforced concrete, structural analysis/design for dynamic loading, and finite element techniques. McCabe is Chairman of ACI Committee 439, Steel Reinforcement, and a member of ACI Committees 408, Bond and Deveopment of Reinforcement; and 446, Fracture Mechanics; and of Joint ACI-ASCE Committee 447, Finite Element Analysis of Reinforced Concrete Structures. He is currently president of the Kansas Chapter of ACI.

strength caused by epoxy coating increases with bar size. The magnitude of the reduction depends on the deformation pattern: bars with relatively large rib bearing areas are affected less by the coating than bars with smaller bearing areas.

This paper describes research to characterize the strength of splices in members containing epoxy-coated reinforcement. The key test parameters are the bar surface condition and the degree of confinement provided by transverse reinforcement. The tests used two bar sizes and three deformation patterns, but the study was not extensive enough to evaluate the effects of either deformation pattern or bar size on splice strength. New development length modification factors for epoxy-coated bars are recommended. Full details of the study are presented by Hester et al. (1991).

\section{RESEARCH SIGNIFICANCE}

Epoxy-coated reinforcing bars are used in concrete structures where corrosion protection is a principal design requirement. The bars exhibit a lower bond strength to concrete than uncoated bars. Considering the increasing application of epoxy-coated reinforcement, the conservatism of current design provisions, and the limited data upon which those provisions are based, an improved understanding of the bond behavior is warranted. The goal is to improve economy and constructability, while maintaining an adequate margin of safety. The current study has special significance because the recommendations presented here are based on 1) the same type of test specimen and 2) over five times the data used to develop the current design provisions.

\section{EXPERIMENTAL PROGRAM}

The experimental program described in this report consisted of 65 beam and slab splice specimens. The specimens were cast and tested in 15 groups of two to six specimens each. All but one group of specimens contained Class B ACI/Class C AASHTO splices (ACI 1989, AASHTO 1989).

\section{Materials}

Reinforcing steel-ASTM A 615 (1989), Grade 60, No. 6 (19-mm) and No. $8(25-\mathrm{mm})$ bars with the same deformation patterns evaluated by Choi et al. (1991), designated S, C, and N, were tested. Grade 40 and Grade 60 No. $3(9.5-\mathrm{mm})$ bars and Grade 60 No. 5 (16-mm) bars were used as transverse reinforcement. Deformation Pattern $S$ consisted of ribs perpendicular to the axis of the bar. Deformation Pattern $C$ consisted of diagonal ribs inclined at an angle of $60 \mathrm{deg}$ with respect to the axis of the bar. Deformation Pattern $N$ consisted of diagonal ribs inclined at an angle of $70 \mathrm{deg}$ with respect to the axis of the bar. Bars of each size and deformation pattern were taken from the same heat of steel. All reinforcement, longitudinal and transverse, within a specimen had the same deformation pattern and surface properties. Yield strengths were as follows: No. 3 bars, Patterns S, C, and N, $68.9,54.1$, and $77.3 \mathrm{ksi}(447,373$, and $533 \mathrm{MPa})$, respectively; No. 5 bars, Pattern C, $72.3 \mathrm{ksi}$ (498 MPa); No. 6 bars, Patterns $S$ and C, 69.5 and $72.4 \mathrm{ksi}(479$ and $499 \mathrm{MPa}$ ), respectively; and No. 8 bars, Patterns $S, C$, and N, 71.1, 69.0, and $63.8 \mathrm{ksi}(490,476$, and $440 \mathrm{MPa})$, respectively. Deformation properties are presented in Appendix A.*

Epoxy coatings were applied in accordance with ASTM A 775 (1989) and ranged in thickness from 7.5 to 11.4 mils $(0.19$ to $0.29 \mathrm{~mm})$ for the beam specimens and from 6.1 to 10.9 mils ( 0.15 to $0.27 \mathrm{~mm}$ ) for the slab specimens, as measured by a pulloff-type thickness gage. Readings were taken at 6 points around the circumference of the bar between each set of deformations within the splice length. Average readings within the splice length are reported.

Concrete-Non-air-entrained concrete containing Type I portland cement and 3/4-in. (19-mm) nominal maximum size coarse aggregate was used. Water-cement ratios ranged from 0.37 to 0.46 and produced concretes with nominal strengths of 5500 or 6000 psi (38 or $41 \mathrm{MPa}$ ). Mix proportions and concrete properties are given in Appendix B. Concrete strengths are listed in Tables 1 and 2 with the test results.

\section{Test specimens}

Two types of test specimens, beam and slab splice specimens, were used. The specimens were supported and loaded to produce a $4-\mathrm{ft}(1.21-\mathrm{m})$ constant moment region, as illustrated in Fig. 1 and 2. All specimens were $13 \mathrm{ft}(3.96 \mathrm{~m})$ long and contained splices that were centered in the constant moment region.

Beam specimens-The beam specimens, shown in Fig. 1, were similar to those tested by Treece and Jirsa $(1987,1989)$ and Choi et al. (1990, 1991). The beams were 16 in. (406 $\mathrm{mm}$ ) wide by 15 or $16 \mathrm{in}$. ( 381 or $406 \mathrm{~mm}$ ) deep and contained 2 or 3 No. 8 bar splices. A splice length of 16 in. (406 mm) was used, except in Group B6, which used a 223/4-in. (578mm) splice length. All bars were bottom-cast with a 2 -in. (50-mm) nominal concrete cover, except for two specimens in Group B3 that had a 1-in. (25-mm) cover. The clear spacing between splices was equal to 3 in. ( $76 \mathrm{~mm}$ ), except in the Group B7 beams, which contained two splices and had a

\footnotetext{
*The appendixes are available in xerographic or similar form from ACI headquarters, where they will be kept permanently on file, at a charge equal to the cost of reproduction plus handling at time of request.
} 
Table 1-Beam splice tests

\begin{tabular}{|c|c|c|c|c|c|c|c|c|c|c|}
\hline \multirow[t]{2}{*}{ Group no. } & \multirow[t]{2}{*}{ Specimen label* } & \multirow{2}{*}{$\begin{array}{l}\text { Number of } \\
\text { splices }\end{array}$} & \multirow{2}{*}{$\begin{array}{l}\text { Average } \\
\text { coating } \\
\text { thickness, } \\
\text { mils }\end{array}$} & \multirow{2}{*}{$\begin{array}{l}\text { Average } \\
\text { cover, in. }\end{array}$} & \multirow{2}{*}{$\begin{array}{l}\text { Concrete } \\
\text { strength, } \\
\text { psi }\end{array}$} & \multirow{2}{*}{$\begin{array}{l}\text { Ultimate } \\
\text { stress, ksi }\end{array}$} & \multicolumn{4}{|c|}{ Relative strength $^{\dagger}$} \\
\hline & & & & & & & $\frac{C}{U}$ & $\frac{U}{U_{n}}$ & $\frac{C}{C_{n}}$ & $\frac{C}{U_{n}}$ \\
\hline B1 & $\begin{array}{l}8 \mathrm{~N} 3-16-0-\mathrm{U} \\
8 \mathrm{~N} 3-16-2-\mathrm{U} \\
8 \mathrm{~N} 3-16-1-\mathrm{C} \\
8 \mathrm{~N} 3-16-2-\mathrm{C} \\
\end{array}$ & $\begin{array}{l}3 \\
3 \\
3 \\
3 \\
\end{array}$ & $\begin{array}{l}0.0 \\
0.0 \\
7.5 \\
9.6 \\
\end{array}$ & $\begin{array}{l}2.00 \\
2.00 \\
2.00 \\
2.00 \\
\end{array}$ & 5990 & $\begin{array}{l}50.4 \\
56.5 \\
38.2 \\
42.7 \\
\end{array}$ & $\frac{-}{\overline{-}}$ & $\begin{array}{c}1.00 \\
1.12 \\
- \\
- \\
\end{array}$ & $\begin{array}{l}- \\
- \\
-\end{array}$ & $\begin{array}{l}- \\
\overline{0.76} \\
0.85 \\
\end{array}$ \\
\hline B2 & $\begin{array}{l}8 C 3-16-0-U \\
8 C 3-16-2-U \\
8 C 3-16-0-C \\
8 C 3-16-2-C \\
\end{array}$ & $\begin{array}{l}3 \\
3 \\
3 \\
3 \\
\end{array}$ & $\begin{array}{c}0.0 \\
0.0 \\
11.2 \\
8.7 \\
\end{array}$ & $\begin{array}{l}1.84 \\
1.83 \\
1.75 \\
1.78 \\
\end{array}$ & 6200 & $\begin{array}{l}46.5 \\
44.2 \\
38.5 \\
38.0 \\
\end{array}$ & $\begin{array}{l}- \\
\overline{0} \\
0.83\end{array}$ & $\begin{array}{l}1.00 \\
0.95 \\
-\end{array}$ & $\begin{array}{l}\overline{-} \\
\overline{1.00} \\
0.99\end{array}$ & $\begin{array}{l}- \\
\overline{-} \\
0.83 \\
0.82 \\
\end{array}$ \\
\hline B3 & $\begin{array}{l}8 S 3-16-0-U \\
8 S 3-16-2-U \\
8 S 3-16-0-C \\
8 S 3-16-2-C \\
8 S 3-16-0-C \\
8 S 3-16-2-C\end{array}$ & $\begin{array}{l}3 \\
3 \\
3 \\
3 \\
3 \\
3 \\
\end{array}$ & $\begin{array}{c}0.0 \\
0.0 \\
9.9 \\
9.8 \\
10.3 \\
9.8 \\
\end{array}$ & $\begin{array}{l}2.04 \\
2.08 \\
2.06 \\
2.07 \\
1.04 \\
1.05 \\
\end{array}$ & 6020 & $\begin{array}{l}47.0 \\
46.6 \\
30.9 \\
32.0 \\
26.5 \\
30.3 \\
\end{array}$ & $\begin{array}{l}\overline{-} \\
\overline{0.66} \\
0.69 \\
- \\
-\end{array}$ & $\begin{array}{l}1.00 \\
0.99 \\
- \\
- \\
- \\
\end{array}$ & $\begin{array}{l}\overline{-} \\
\overline{1.00} \\
1.04 \\
1.00 \\
1.14\end{array}$ & $\begin{array}{l}- \\
\overline{-} \\
0.66 \\
- \\
-\end{array}$ \\
\hline B4 & $\begin{array}{l}8 S 3-16-0-U \\
8 S 3-16-2-U \\
8 S 3-16-3-U \\
8 S 3-16-0-C \\
8 S 3-16-2-C \\
8 S 3-16-3-C\end{array}$ & $\begin{array}{l}3 \\
3 \\
3 \\
3 \\
3 \\
3 \\
\end{array}$ & $\begin{array}{c}0.0 \\
0.0 \\
0.0 \\
10.7 \\
9.8 \\
8.9 \\
\end{array}$ & $\begin{array}{l}2.10 \\
2.04 \\
2.10 \\
2.11 \\
2.00 \\
2.03 \\
\end{array}$ & 6450 & $\begin{array}{l}42.7 \\
47.4 \\
50.4 \\
30.8 \\
32.1 \\
30.8 \\
\end{array}$ & $\begin{array}{l}\overline{-} \\
\overline{0} \\
0.72 \\
0.68 \\
\end{array}$ & $\begin{array}{l}1.00 \\
1.11 \\
1.18 \\
- \\
- \\
\end{array}$ & $\begin{array}{l}- \\
\overline{-} \\
1.00 \\
1.04 \\
1.00\end{array}$ & $\begin{array}{l}- \\
\overline{-} \\
0.72 \\
0.75 \\
0.72 \\
\end{array}$ \\
\hline B5 & $\begin{array}{l}8 \mathrm{C} 3-16-0-U \\
8 \mathrm{C} 3-16-2-U \\
8 \mathrm{C} 3-16-3-U \\
8 \mathrm{C} 3-16-0-C \\
8 \mathrm{C} 3-16-3-\mathrm{C} \\
\end{array}$ & $\begin{array}{l}3 \\
3 \\
3 \\
3 \\
3 \\
\end{array}$ & $\begin{array}{l}0.0 \\
0.0 \\
0.0 \\
8.6 \\
8.0 \\
\end{array}$ & $\begin{array}{l}2.05 \\
2.06 \\
2.06 \\
2.01 \\
2.06 \\
\end{array}$ & 5490 & $\begin{array}{l}39.7 \\
46.6 \\
43.2 \\
31.8 \\
34.7 \\
\end{array}$ & $\begin{array}{l}\overline{-} \\
\overline{0.80} \\
0.80\end{array}$ & $\begin{array}{l}1.00 \\
1.17 \\
1.09 \\
- \\
- \\
\end{array}$ & $\begin{array}{l}- \\
\overline{-} \\
1.00 \\
1.09\end{array}$ & $\begin{array}{l}- \\
\overline{-} \\
0.80 \\
0.87\end{array}$ \\
\hline B6 & $\begin{array}{l}8 C 3-22^{3} / 4-0-U \\
8 C 3-223 / 4-3-U \\
8 C 3-223 / 4-4-U \\
8 C 3-223 / 4-0-C \\
8 C 3-223 / 4-3-C \\
8 C 3-223 / 4-4-C\end{array}$ & $\begin{array}{l}3 \\
3 \\
3 \\
3 \\
3 \\
3\end{array}$ & $\begin{array}{l}0.0 \\
0.0 \\
0.0 \\
9.0 \\
8.6 \\
9.9\end{array}$ & $\begin{array}{l}2.15 \\
2.17 \\
2.16 \\
2.00 \\
2.13 \\
2.18\end{array}$ & 5850 & $\begin{array}{l}51.6 \\
56.2 \\
55.6 \\
33.4 \\
35.6 \\
38.5\end{array}$ & $\begin{array}{l}- \\
\overline{-} \\
0.65 \\
0.63 \\
0.69\end{array}$ & $\begin{array}{l}1.00 \\
1.09 \\
1.08 \\
- \\
-\end{array}$ & $\begin{array}{l}- \\
\overline{-} \\
1.00 \\
1.07 \\
1.16\end{array}$ & $\begin{array}{l}\bar{Z} \\
\overline{0} \\
0.65 \\
0.69 \\
0.75\end{array}$ \\
\hline B7 & $\begin{array}{l}8 C 3-16-0-U \\
8 C 3-16-3-U \\
8 C 3-16-0-C \\
8 C 3-16-3-C \\
\end{array}$ & $\begin{array}{l}2 \\
2 \\
2 \\
2 \\
\end{array}$ & $\begin{array}{c}0.0 \\
0.0 \\
11.4 \\
9.9 \\
\end{array}$ & $\begin{array}{l}2.12 \\
2.03 \\
2.12 \\
2.08 \\
\end{array}$ & 5240 & $\begin{array}{l}45.2 \\
51.5 \\
38.7 \\
38.7 \\
\end{array}$ & $\begin{array}{l}- \\
\overline{0.86} \\
0.75\end{array}$ & $\begin{array}{l}1.00 \\
1.14 \\
- \\
- \\
\end{array}$ & $\begin{array}{l}-\overline{-} \\
1.00 \\
1.00\end{array}$ & $\begin{array}{l}\overline{-} \\
0.86 \\
0.86 \\
\end{array}$ \\
\hline $\begin{array}{l}\text { *Specimen } \\
\text { C Cor coate- } \\
\dagger U=\text { uncoat } \\
\text { All bars bot } \\
\text { Nominal co } \\
1 \text { mil }=0.00\end{array}$ & $\begin{array}{l}\text { ADS } L-N-B, \text { where } \\
\text { st. } \\
\text { ed for } B 1 \text { because c } \\
\text { in. }=25.4 \mathrm{~mm} ; 1\end{array}$ & $\begin{array}{l}\text { at was not } \\
=6.89 \mathrm{kPa} \text {; }\end{array}$ & $\begin{array}{l}\text { formation } \\
\text { a splice le } \\
\text { red for } \mathrm{Gr} \\
=6.89 \mathrm{MF}\end{array}$ & rn S, C, & $S=$ stimup & $\operatorname{size} ; L=\mathrm{spli}$ & $\frac{\text { mean }=0.72}{\text { ice length, in; } N=}$ & . & & oated ba \\
\hline
\end{tabular}

clear spacing of 8 in. $(203 \mathrm{~mm})$. The side cover on the longitudinal bars was equal to 2 in. $(50 \mathrm{~mm})$ for all beam specimens. Specimens contained $0,1,2,3$, or 4 No. 3 bar stirrups within the splice region. In Groups B1 through B3, the stirrups were placed closer to the center of the splice, while in groups B4 through B7, the outer stirrups were centered $1 \frac{1}{4}$ in. $(32 \mathrm{~mm}$ ) from the ends of the splice. For the configurations used, the exact stirrup placement did not appear to affect splice strength.

Slab specimens - The slab specimens were similar to those tested by Cleary and Ramirez $(1989,1991)$. The slabs were $24 \mathrm{in} .(610 \mathrm{~mm})$ wide by $8 \mathrm{in}$. $(203 \mathrm{~mm})$ deep and had a nominal cover of 2 in. $(50 \mathrm{~mm})$ (Fig. 2). The specimens contained top-cast No. 6 (Groups S1 through S4, S7, and S8) or No. 8 (Groups S5 and S6) bars and used No. 3 (Groups
S1 through S3) or No. 5 (Groups S4 through S8) bars as transverse reinforcement. Zero, two, or four closed stirrups were used within the splice regions. The outer stirrups were placed 1 or 2 in. ( 25 or $50 \mathrm{~mm}$ ) from the ends of the splices. Splice lengths were 10 in. $(254 \mathrm{~mm})$ for No. 6 bars and 16 in. $(406 \mathrm{~mm})$ for No. 8 bars. Groups S1 through S6 contained three splices. Group $\$ 7$ contained a single splice with two continuous bars through the splice region. Group S8 contained two splices with a single continuous bar through the splice region. Specimens with No. 6 bars had a side cover of $3 \frac{1}{4}$ in. $(83 \mathrm{~mm})$ and a clear spacing of $61 / 2$ in. $(165 \mathrm{~mm})$ between splices. Specimens with No. 8 bars had a side cover of $3 \mathrm{in}$. (76 mm) and a clear spacing of $6 \mathrm{in.}(152 \mathrm{~mm}$ ) between splices. The vertical legs of the stimups had a side cover of 1 in. $(25 \mathrm{~mm})$. As illustrated in Fig. 2, the slab 
Table 2-Slab splice tests

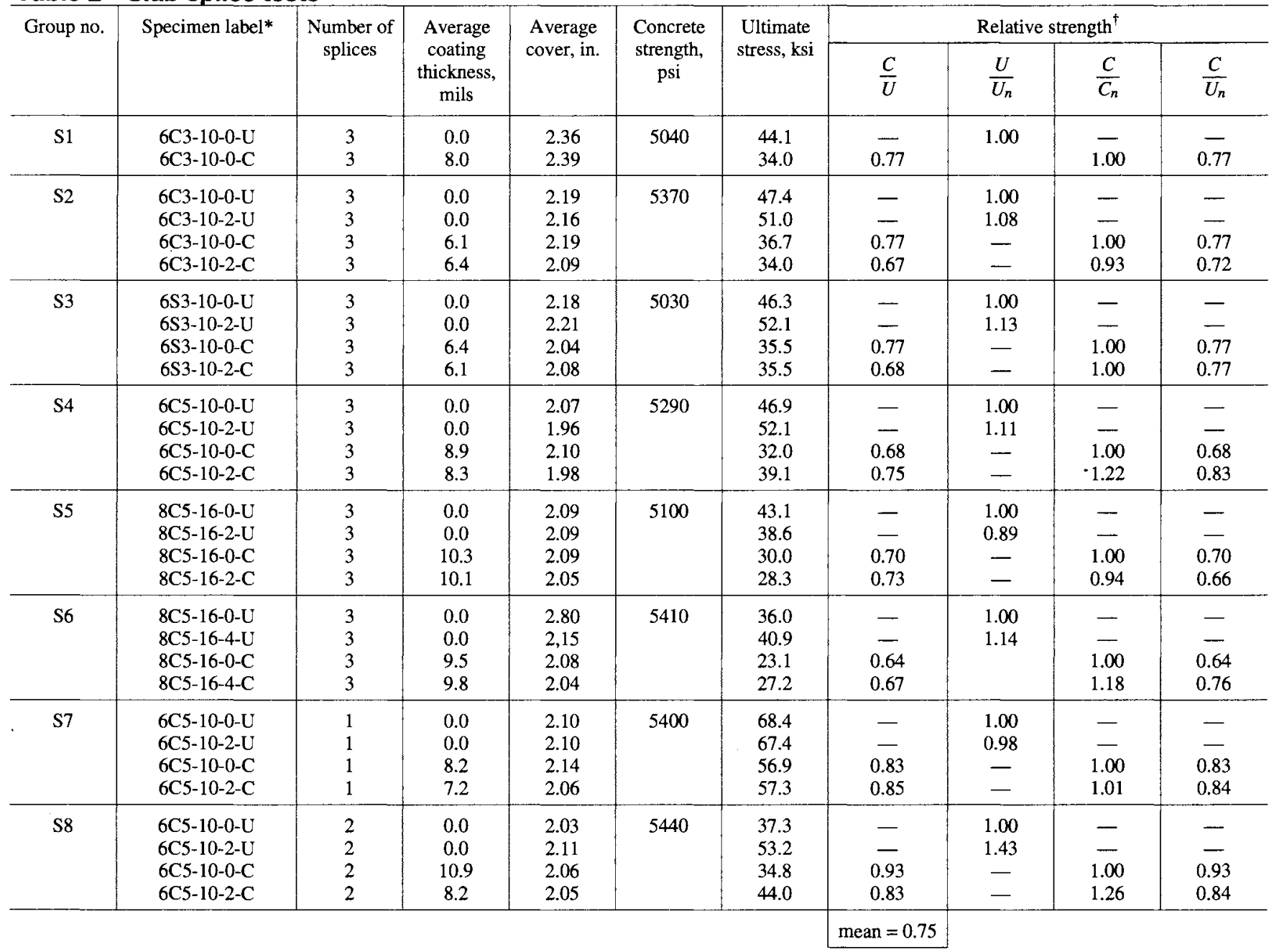

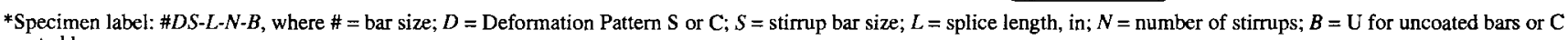
for coated bars.

$\mathrm{U}=$ uncoated bars; $C=$ coated bars; and $n=$ no stirrups within splice length

All bars top-cast.

$1 \mathrm{mil}=0.001$ in.; 1 in. $=25.4 \mathrm{~mm} ; 1 \mathrm{psi}=6.89 \mathrm{kPa} ; 1 \mathrm{ksi}=6.89 \mathrm{MPa}$

specimens were detailed so that the transverse reinforcement provided confinement only for vertical, not horizontal, splitting. -

Tables 1 and 2 provide additional details on specimen configuration.

\section{Test procedure}

The specimens were tested at nominal concrete compressive strengths of 5500 or $6000 \mathrm{psi}(38$ to $41 \mathrm{MPa}$ ). The beam specimens were inverted, and both types of specimens were tested as inverted simply supported beams, as illustrated in Fig. 1 and 2. The specimens were loaded monotonically until failure.

\section{Results and observations}

Typical load-deflection curves are illustrated in Fig. 3 (Group S4). Specimens containing epoxy-coated bars consistently failed at a lower load than those containing uncoated bars. As a general rule, splices confined by transverse reinforcement exhibited higher strengths than splices without transverse reinforcement. As shown in Fig. 3, the load-de- flection curves for most specimens within a test group were very close up to the point of failure. However, in Groups S1 and S6, the slabs containing epoxy-coated bars exhibited a lower cracking load than the slabs with uncoated steel (Hester et al. 1991).

Specimens without stirrups failed in a brittle manner, with the load dropping immediately after the specimen attained the peak load. In contrast, specimens with stirrups behaved in a ductile manner, with the load dropping slowly as additional deflection was applied.

The test results are summarized in Tables 1 and 2 for the beam and slab test specimens, respectively.

The ratio of the strength of specimens containing epoxycoated bars to similar specimens containing uncoated bars $C / U$ ranged from 0.61 to 0.86 for the beam specimens and from 0.64 to 0.93 for the slab specimens. All of the tests in the current study resulted in a splitting failure; however, the nature of the failure was different in the beam and slab specimens.

In the beam specimens, failure was accompanied by extensive longitudinal and transverse cracking in the region of 
the splices. Following failure, a horizontal crack through the plane of the spliced bars, extending the length of the splice region, was evident, as shown schematically in Fig. 4(a). The concrete cover was easily removed with a hammer, exposing a nearly horizontal crack running the full width of the beam in the plane of the splices, as observed in earlier tests (Treece and Jirsa 1987, 1989; Choi et al., 1990, 1991).

In the slab specimens, where the bars were separated by a minimum of 6 bar diameters, little horizontal cracking was evident. Rather, cracks propagated from the spliced bars at about 45 deg with the horizontal, as shown schematically in Fig. 4(b). For specimens without transverse reinforcement, this resulted in intact regions of concrete between the splices, i.e., little cover was lost between the splices. Specimens with transverse reinforcement tended to have somewhat less intact concrete than specimens without transverse reinforcement.

As observed in earlier studies (Johnston and Zia 1982; Treece and Jirsa 1987, 1989; Choi et al. 1990, 1991; Choi, Darwin, and McCabe 1990), the epoxy-coated bars were clean following failure, with no concrete residue left on the bars; the concrete in contact with the epoxy-coated bars had a smooth, glassy surface. In contrast, the uncoated bars had particles of cement paste and mortar on the shaft and side of the deformations following failure. In a few cases, bars in beam specimens showed signs of the epoxy coating being crushed against the concrete, but, in general, the epoxy was undamaged. For the slab specimens, no damage to the epoxy was observed.

\section{EVALUATION OF EXPERIMENTAL RESULTS}

The principal goals of this paper are to evaluate the effects of transverse reinforcement on the strength of spliced epoxy-coated reinforcement and to develop suitable development length modification factors for use in design to account for the effects of epoxy coating. A total of 113 tests are used in the analysis that follows.

In addition to the 65 specimens in the current study, the results of the 21 splice tests by Treece and Jirsa $(1987,1989)$, 15 splice tests by Choi et al. $(1990,1991)$, and 12 splice tests by Hamad and Jirsa (1990) are used for the overall evaluation (data available in Appendix C). Hamad and Jirsa (1990) used transverse reinforcement. The other two previous studies did not.

In the next three sections, the points of specific interest include the effect of transverse reinforcement on the relative strengths of similar specimens containing coated and uncoated reinforcement $C / U$; the relative strength of members with transverse reinforcement compared to members without transverse reinforcement $C / C_{n}$ for coated bars and $U / U_{n}$ for uncoated bars; and the relative strength of members with coated bars, both with and without transverse reinforcement, compared to members with uncoated bars without transverse reinforcement $C / U_{n}$. In these comparisons, the results for the 12 tests by Hamad and Jirsa (1990) are combined with the 65 tests in the current study. The discussion of the effects of transverse reinforcement is followed by comparisons of all 113 tests with design provisions (AASHTO 1989, ACI 1989) and a predictive equation (Orangun, Jirsa, and Breen 1977).
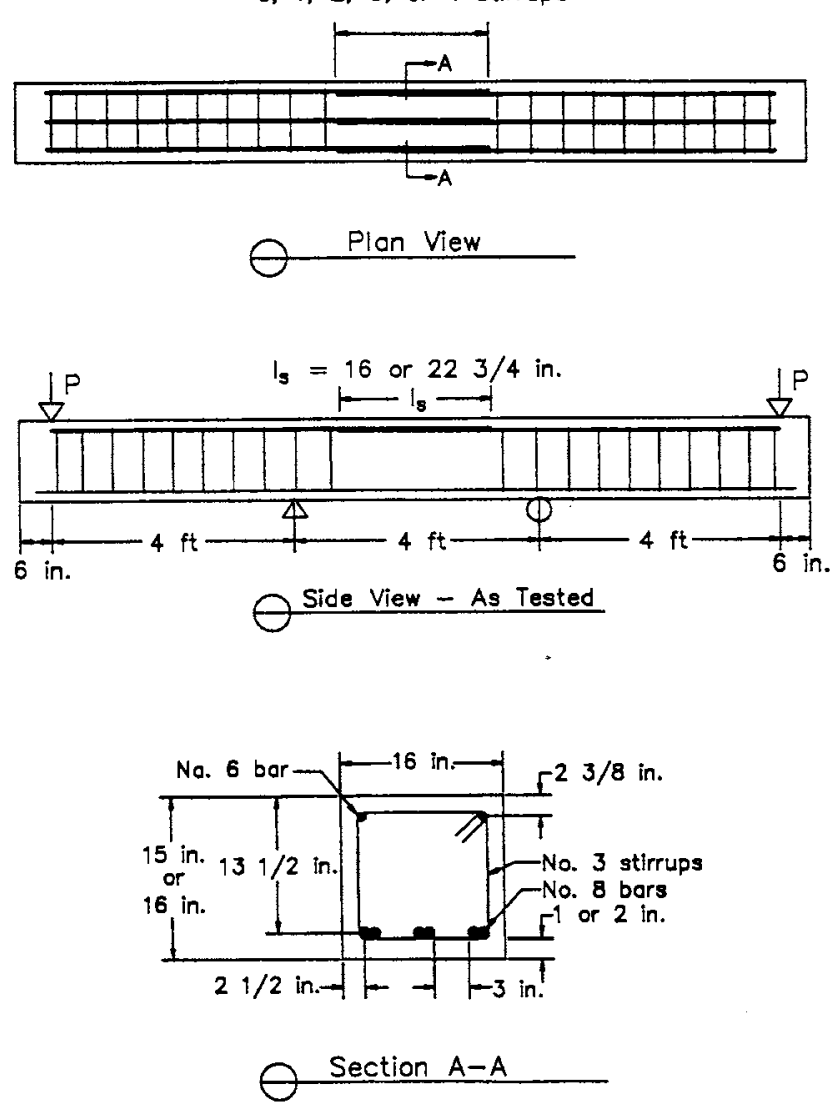

Fig. 1 -Beam splice specimens: 1 in. $=25.4 \mathrm{~mm} ; 1 \mathrm{ft}=305$ $\mathrm{mm}$
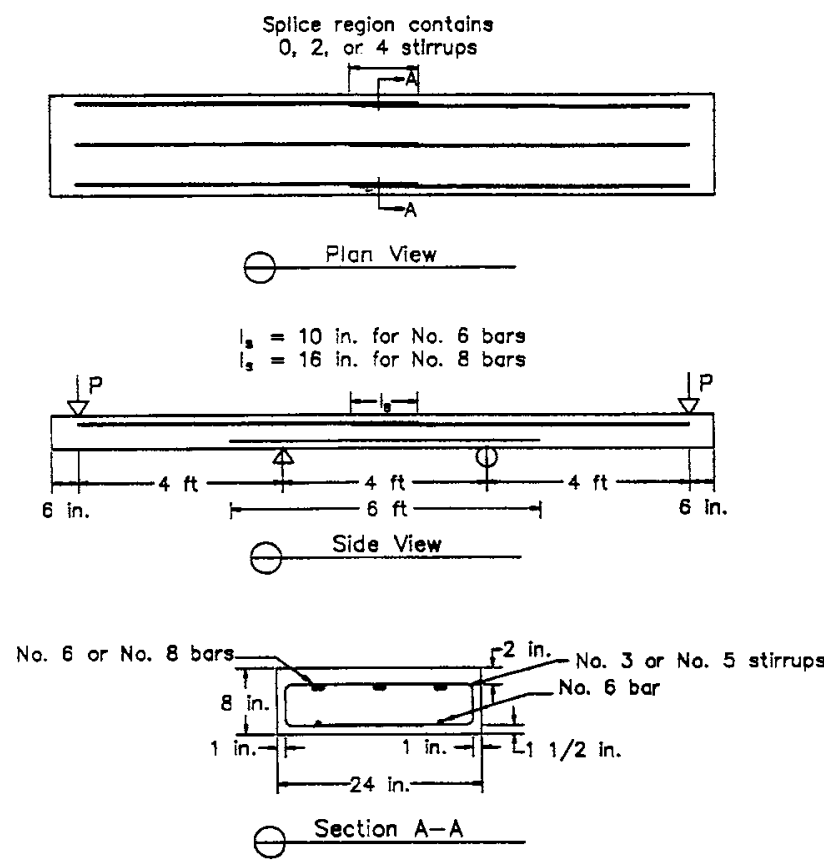

Fig. 2- Slab splice specimens: $1 \mathrm{in} .=25.4 \mathrm{~mm} ; 1 \mathrm{ft}=305$ $\mathrm{mm}$

\section{Effect of transverse reinforcement-Coated bars relative to uncoated bars}

The first comparisons involve the effect of transverse reinforcement on the value of $C / U$ for specimens that, except 


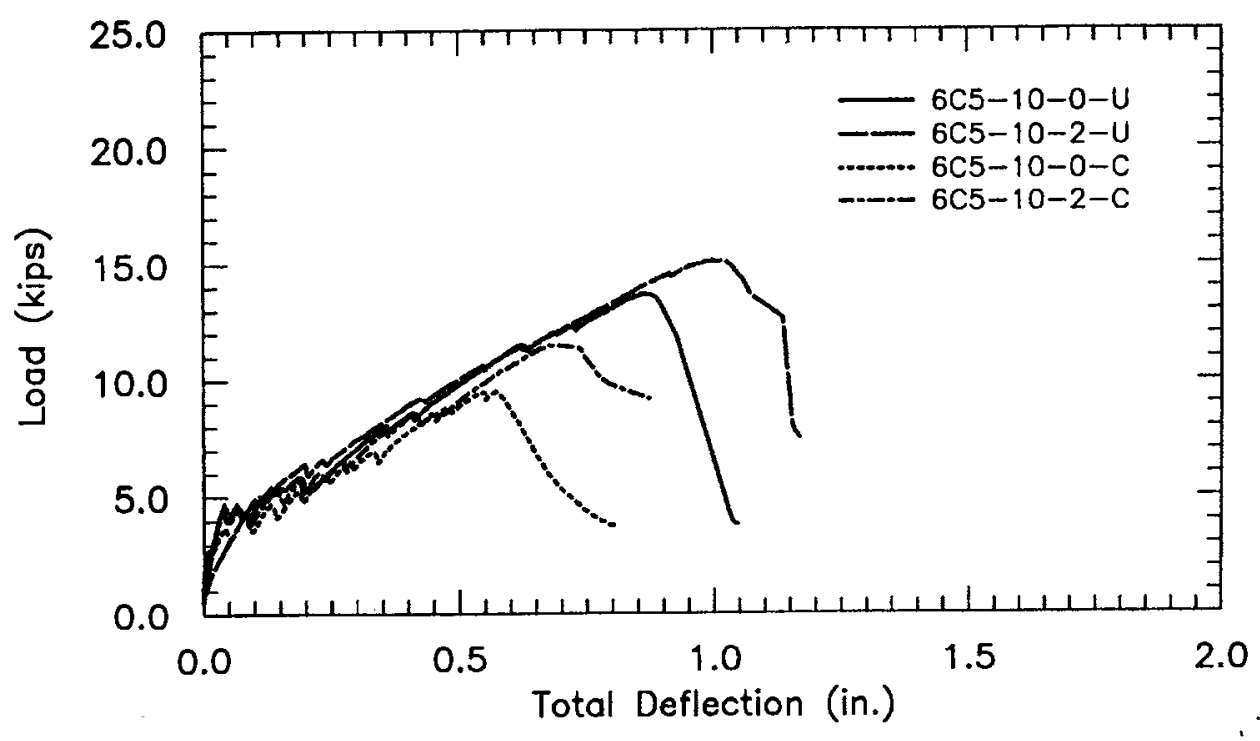

Fig. 3-Load-deflection curves for slabs in Group S4: 1 kip $=6.89 \mathrm{MPa} ; 1 \mathrm{in} .-25.4 \mathrm{~mm}$
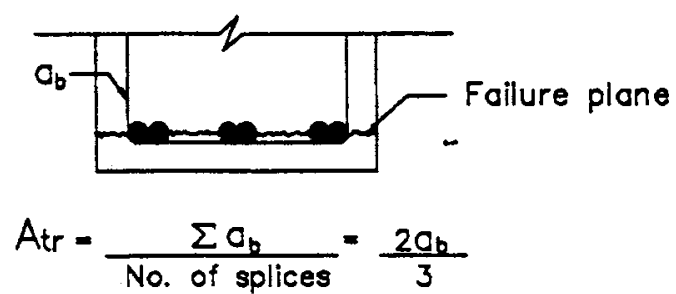

(a)

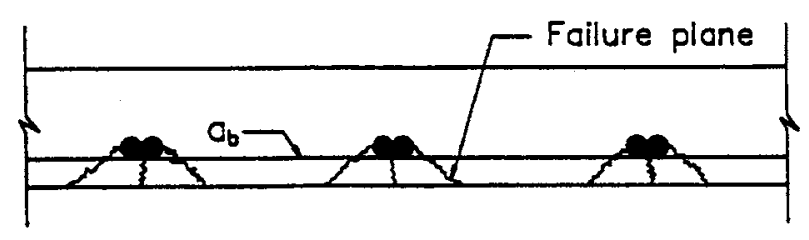

Atr $=\frac{\sum a_{b}}{\text { No. of splices }}=\frac{a_{b}}{1}=a_{b}$

(b)

Fig. 4-Schematic of splice failure and definition of area of transverse reinforcement: (a) for center-to-center spacing < 6 in.; (b) for center-to-center spacing $\geq 6$ in.

for the surface of the reinforcement, are essentially identical. The values of $C / U$ for the current study are listed in Tables 1 and 2 and are plotted, along with the values from Hamad and Jirsa (1990), in Fig. 5 as a function of the size, yield strength, and spacing of the transverse reinforcement, expressed as the variable $K_{t r}$ (Orangun, Jirsa, and Breen 1977)

$$
K_{t r}=\frac{A_{t r} f_{y t}}{500 s d_{b}}
$$

in which $A_{t r}=$ area of transverse reinforcement normal to the plane of splitting per developed/spliced bar (see Fig. 4), in. $^{2} ; f_{y t}=$ yield strength of transverse reinforcement, psi; $s$ = spacing of transverse reinforcement, center-to-center, or development/splice length divided by the number of stirrups, in.; and $d_{b}=$ diameter of developed/spliced bars, in.

Each data point in Fig. 5 represents the ratio of the bar stress at failure for a member containing epoxy-coated bars to the bar stress in a similar member in the same test group with uncoated bars. The lines represent the best fit for each test group obtained using the technique of dummy variables (Draper and Smith 1981). The technique uses the assumption that, while there may be differences in the value of $C / U$ due to deformation pattern and member configuration, the change in $C / U$ due to transverse reinforcement is the same in all cases.

Fig. 5 illustrates that the value of $C / U$ is nearly independent of transverse reinforcement. The slope of the best-fit lines is -0.001 , resulting in a change in the value of $C / U$ of only -0.01 as $K_{t r}$ increases from 0 to 10 . This insensitivity is expected, based on the finite element analyses of Choi, Darwin, and McCabe (1990) and the experimental bond study of bars subjected to a confining force by Hamad and Jirsa (1990).

In the original formulation by Orangun, Jirsa, and Breen (1977), the maximum effective value of $K_{t r}$ was set at 3.0. If the results illustrated in Fig. 5 are analyzed for members with $K_{t r} \leq 3$, the slope remains flat at 0.001 .

This analysis strongly suggests that a single epoxy-coated bar development length modification factor could be used, whether transverse reinforcement is used or not, if other aspects affecting bond are accounted for properly. The mean value of the intercepts of the best fit lines at $K_{t r}=0$ is 0.74 in Fig. 5.

\section{Effect of transverse reinforcemen-Bars with same-surface properties}

Fig. 6 illustrates the effect of transverse reinforcement on the strength of splices for bars that have the same surface properties. In this figure, each data point represents the ratio for a specimen with transverse reinforcement to a similar 


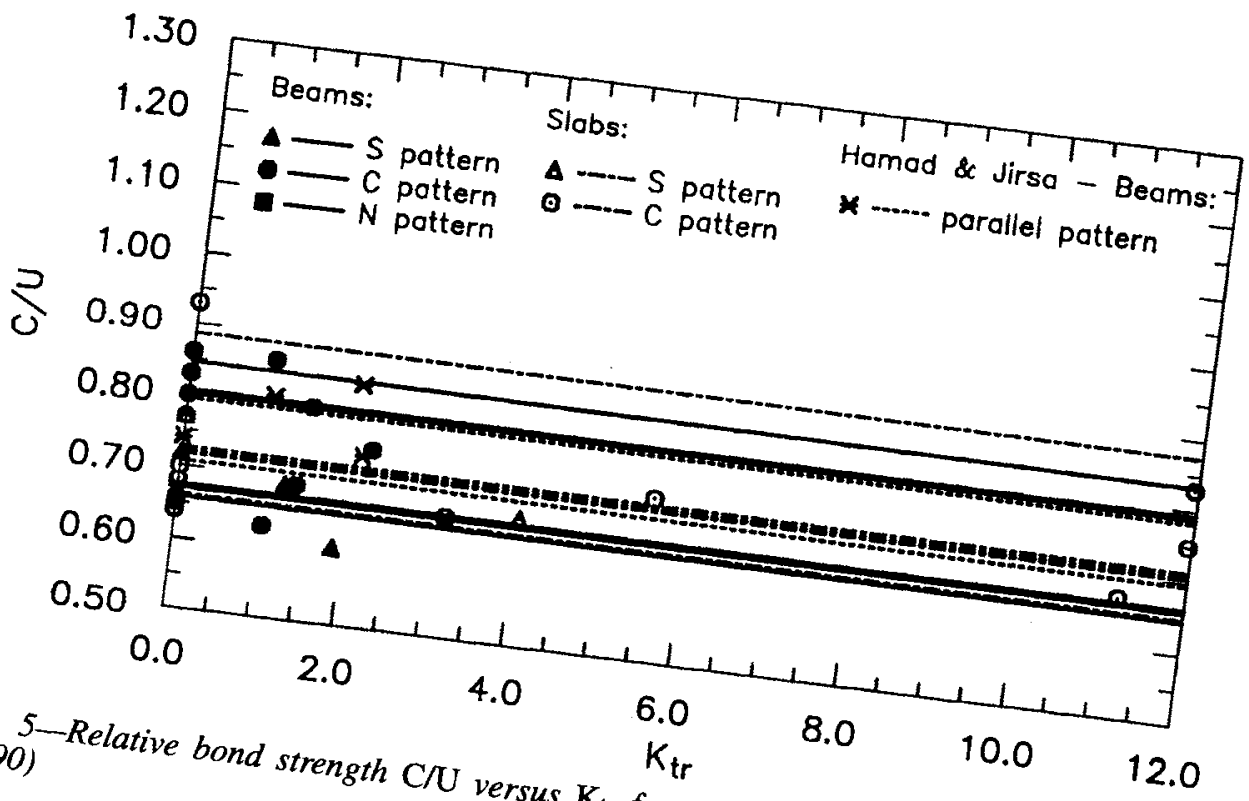

$\begin{array}{lllll}\text { Fig. 5-Relative bond strength } \mathrm{C} / \mathrm{U} & \mathrm{K}_{\mathrm{tr}} & 8.0 & 10.0 & 12.0 \\ \text { (1990) }\end{array}$

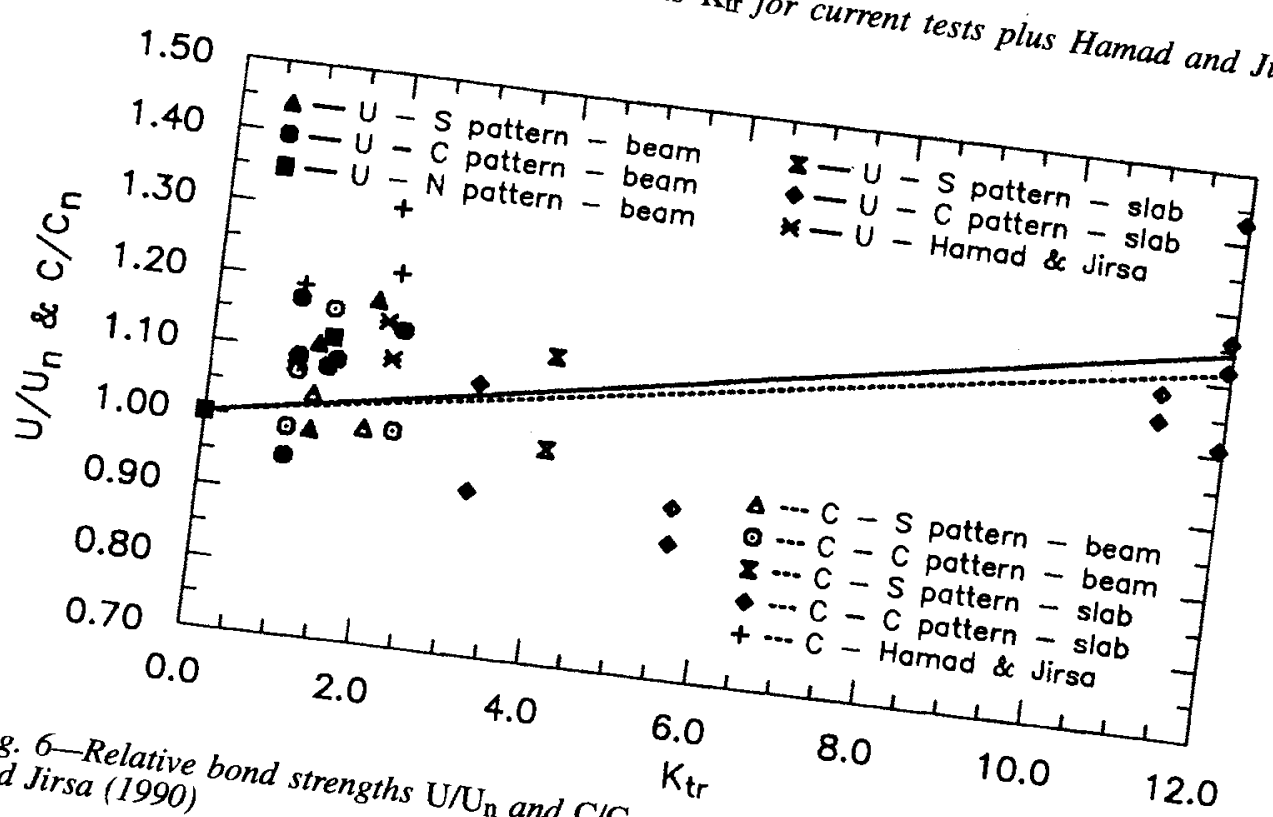

$\begin{array}{lllll}\text { Fig. } 6 \text {-Relative bond strengths } \mathrm{U} / \mathrm{U} & \mathrm{K}_{\mathrm{tr}} & 8.0 & 10.0 & 12.0\end{array}$

and Jirsa (1990) 12.0

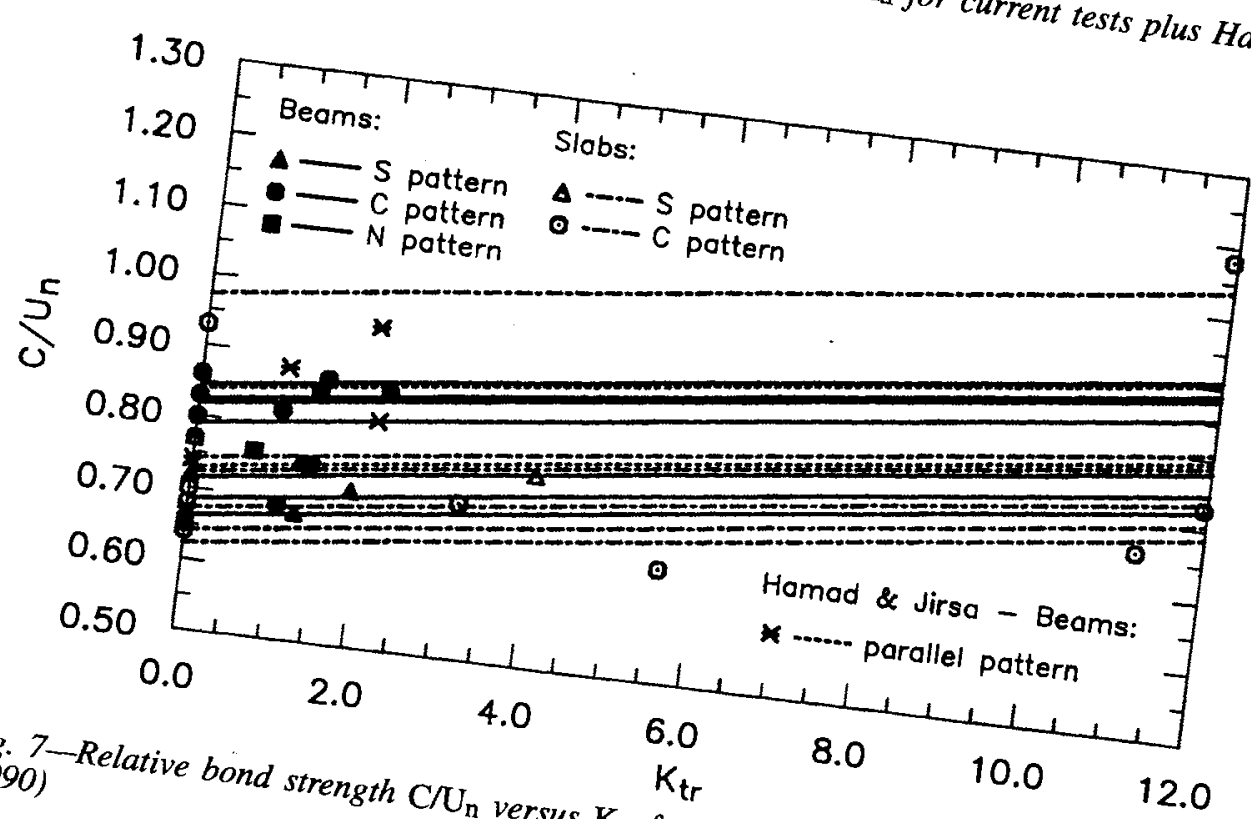

$\begin{array}{lllll}\text { Fig. 7-Relative bond strength } \mathrm{C} / \mathrm{U}_{\mathrm{n}} & \mathrm{K}_{\mathrm{tr}} & 8.0 & 10.0 & 12.0\end{array}$

versus $K_{\text {tr }}$ for current tests plus Hamad and Jirsa 
specimen from the same test group without transverse reinforcement $\left(C / C_{n}\right.$ for coated bar specimens and $U / U_{n}$ for uncoated bar specimens). The data are quite scattered; however, overall trends can be obtained using best-fit lines passing through the point 1.0 at a value of $K_{t r}=0$. Fig. 6 illustrates that transverse reinforcement has a significant effect on splice strength. The slopes of the $C / C_{n}$ and $U / U_{n}$ lines are within 10 percent of each other, at 0.0181 and 0.0204 , respectively. If the results illustrated in Fig. 6 are analyzed for members with $K_{t r} \leq 3.0$, the slopes of the $C / C_{n}$ and $U / U_{n}$ lines are nearly identical at 0.0655 and 0.0654 , respectively. The higher slopes for specimens with lower values of $K_{t r}$ support the observations by Orangun, Jirsa, and Breen (1977) that, above $K_{t r}=3.0$, additional transverse reinforcement is not particularly effective. The similarity in the effect of transverse reinforcement on the splice strength of coated and uncoated reinforcement is expected, based on the insensitivity of $C / U$ to $K_{t r}$ observed in Fig. 5. Thus, the percentage increase in splice strength with the addition of transverse reinforcement is about the same for coated and uncoated bars.

\section{Effect of transverse reinforcement-Coated bars relative to uncoated bars without transverse reinforcement}

The ratios of the splice strengths of specimens containing epoxy-coated bars, both with and without transverse reinforcement, to the splice strengths of specimens with uncoated reinforcement and no transverse reinforcement in the same test group $C / U_{n}$ are compared to $K_{t r}$ in Fig. 7 using the technique of dummy variables. The figure illustrates, as does Fig. 6, that transverse reinforcement can have a significant effect on the useful splice capacity of epoxy-coated bars. For specimens without transverse reinforcement $\left(K_{t r}=0\right)$, the average value of $C / U_{n}$ is 0.75 , a close match with the average value of 0.74 at $K_{t r}=0$ obtained from Fig. 5. Considering only members with $K_{t r} \leq 3.0$, the average value of $C / U_{n}$ rises to 0.87 at $K_{t r}=3.0$.

Based on Fig. 5 and 7, the splice length for coated bars without transverse reinforcement should be $1 / 0.74=1.35$ times longer than used for uncoated bars without transverse reinforcement. Likewise, the splice length of coated bars with transverse reinforcement and $K_{t r}=3.0$ could be as low as $1 / 0.87=1.15$ times longer than used for uncoated bars without transverse reinforcement. The latter number is significant for bridge design since the 1989 AASHTO Bridge Specifications do not take advantage of the higher bond strength obtained with transverse reinforcement.

A note of caution is necessary. If the results of Hamad and Jirsa (1990) are excluded from the analysis for $K_{t r} \leq 3.0$, $C / U_{n}$ at $K_{t r}=3.0$ is 0.82 , which translates to a development length modification factor of 1.22 . Thus, without running additional tests, it would be prudent to use a development length modification factor that is closer to 1.22 than to 1.15 .

In the next section, the test results are compared to values obtained from predictive equations.

\section{Comparison with predictive equations}

Predictive equations-The test results from the current study, along with the results of splice tests by Hamad and
Jirsa (1990), Treece and Jirsa (1987, 1989), and Choi et al. (1990, 1991), are compared with the design equations in the AASHTO Bridge Specifications (1989), which coincide with those of the 1983 ACI Building Code, the provisions of $\mathrm{ACI}$ $318-89$, and the predictive equation of Orangun, Jirsa, and Breen (1977). For the purposes of comparison, epoxy-coated bar factors (AASHTO 1989, ACI 1989) are not used in these calculations.

The expression for the basic development length is the same in the AASHTO Bridge Specifications (1989) and ACI 318-89. The basic development length $l_{d}$, in inches, is given by

$$
l_{d}=\frac{0.04 A_{b} f_{y}}{\sqrt{f_{c}^{\prime}}}
$$

in which $A_{b}=$ area of an individual bar, in. ${ }^{2} ; f_{y}=$ yield strength of reinforcement, psi; and $\sqrt{f_{c}^{\prime}}=$ the square root of concrete compressive strength, psi.

Substituting the splice length $l_{s}$ for $l_{d}$, and the bar stress $f_{s}$ for the yield strength $f_{y}$, and solving for $f_{s}$ provides an expression for the predicted bar stress at failure

$$
f_{s}=\frac{l_{s} \sqrt{f_{c}^{\prime}}}{0.04 A_{b}}=\frac{25 l_{s} \sqrt{f_{c}^{\prime}}}{A_{b}}
$$

The AASHTO (1989) design provisions provide that the basic development length in Eq. (2) may be decreased by 20 percent for reinforcement that is spaced laterally at least 6 in. on center and has at least 3 in. of cover measured in the direction of the spacing. ACI 318-89 uses the same factor, but with the 6 -in. and 3-in. criteria replaced with 5- and 21/2-bar diameter clear spacing requirements. A 20 percent reduction in $l_{d}$ (or $l_{s}$ ) means that the stress $f_{s}$ in Eq. (3) should be modified by a factor of $1 / 0.8=1.25$. This factor applies to all of the slabs tested in this study (Groups S1 through S7).

Under the AASHTO (1989) provisions, an additional factor of $1 / 1.7$ is applied to $f_{s}$ for most tests evaluated to account for the use of AASHTO Class C splices (more than 50 percent of the reinforcement spliced within the lap length). The 1/1.7 factor is not used to modify the values of $f_{s}$ from Group S7, since those slabs contained Class A splices.

Under the provisions of ACI $318-89, f_{s}$ is modified by 1/1.3 to account for the use of ACI Class B splices. Like the AASHTO Class $C$ splice provision, this provision applies to all specimens evaluated, except those in Group S7. Under the provisions of Section 12.2.3 of ACI 318-89, an additional modification factor, $1 / 2.0$, is applied to $f_{s}$ for two beams in Group B3 because of low cover (less than two bar diameters). Factors of $1 / 2.0$ or $1 / 1.4$ for low cover (see Section 12.2.3 of ACI 318-89) are also applied for a number of other tests (Treece and Jirsa 1987, 1989; Choi et al. 1990, 1991; Hamad and Jirsa 1990) that are analyzed in this paper.

Both the AASHTO (1989) and ACI (1989) provisions include factors for top reinforcement (horizontal reinforcement so placed that more than 12 in. $(305 \mathrm{~mm})$ of fresh concrete is cast in the member below the reinforcement). These factors, 1.4 and 1.3 , respectively, are included in the 


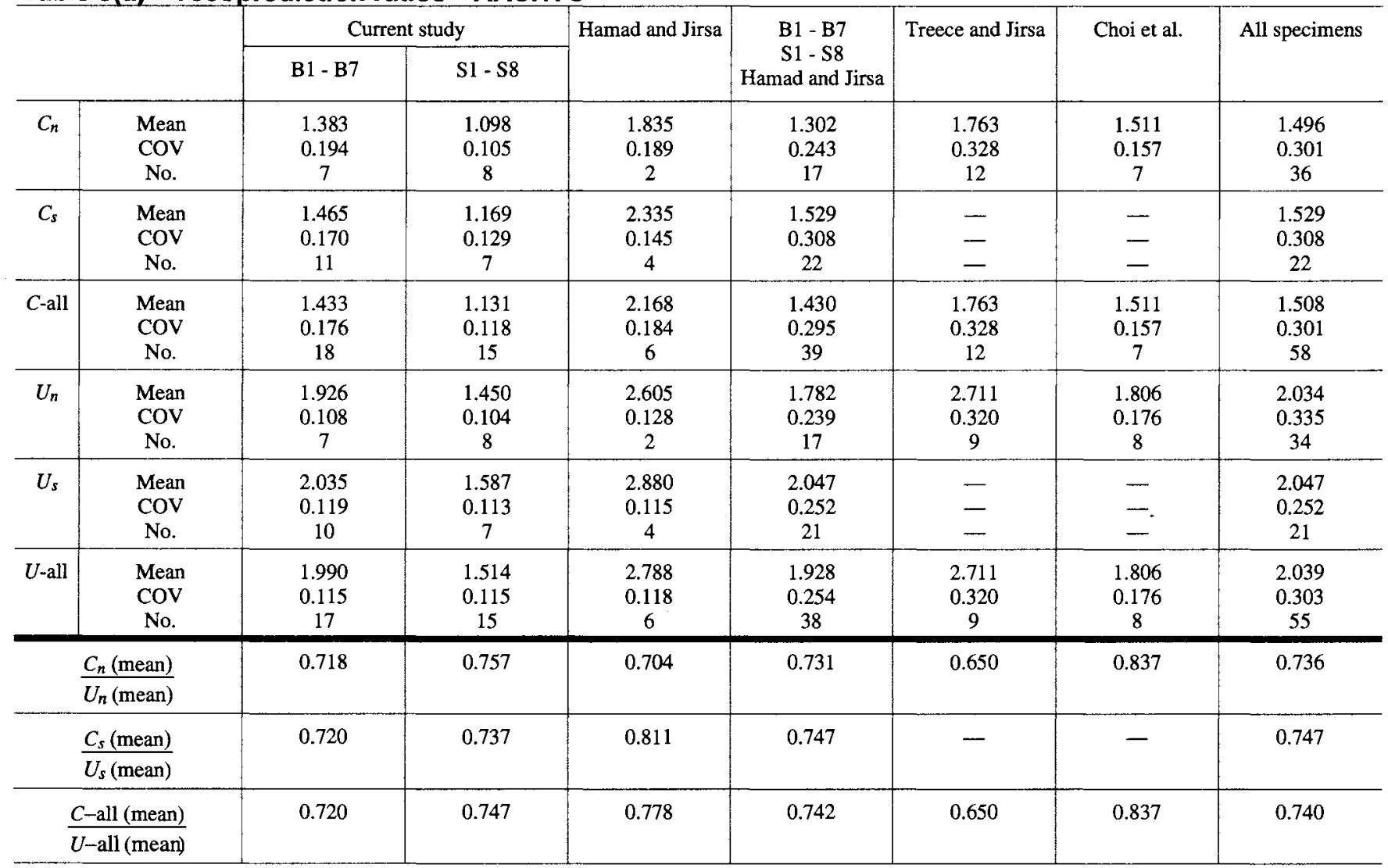

COV = coefficient of variation; No. $=$ number of specimens; $C=$ coated bars; $U=$ uncoated bars; $n=$ no stimups within splice length; $s=$ stimups within splice length.

current analysis. The top-reinforcement, or top-bar, factor must be applied to tests by Treece and Jirsa $(1987,1989)$ and Hamad and Jirsa (1990).

The expression used by Orangun, Jirsa, and Breen (1977) to predict splice strength is given in Eq. (4) in terms of steel stress at failure.

$$
f_{s}=\left[1.2+\frac{3 C}{d_{b}}+\frac{50 d_{b}}{l_{s}}+\frac{A_{t r} f_{y t}}{500 s d_{b}}\right] \frac{4 l_{s} \sqrt{f_{c}^{\prime}}}{d_{b}}
$$

in which $C=$ smaller of bottom (top) cover or one-half of clear spacing between splices. The Orangun, Jirsa, and Breen (1977) predictions include no provision for top reinforcement.

Comparisons - The results of the comparisons of the predictive equations with the tests from the current study, plus the tests by Treece and Jirsa $(1987,1989)$, Choi et al. (1990a, 1991), and Hamad and Jirsa (1990), are listed in Appendix $\mathrm{D}$ and summarized in Table 3 . As stated earlier, the comparisons do not include the AASHTO or ACI epoxy-coated bar factors.

Tables 3(a) through (c) contain summaries of the comparisons with test results for the AASHTO (1989), ACI (1989), and Orangun, Jirsa, Breen (1977) predictions, respectively. The results are grouped by bar surface (coated and uncoated), use of transverse reinforcement (no stirrups or stirrups within the splice length), and test series (B1-B7, S1-S8, Hamad and Jirsa, Treece and Jirsa, Choi et al.). In addition to comparisons based on individual test series, the comparisons for the three groups that include transverse reinforcement, B1-B7 and S1-S8 from the current study and the beams tested by Hamad and Jirsa (1990), are combined. Overall comparisons for all test specimens are also included. For each category, comparisons are made based on the mean value of the ratio of the test strength to the predicted strength and the coefficient of variation (COV). The number of specimens in each category is indicated. Tables 3(a) through (c) also include a summary of the values of $C / U$ based on the mean test/prediction ratios for each category.

The comparisons indicate that, on average, the experimental splice strengths exceed those predicted by the design expressions (AASHTO 1989; ACI 1989) for both coated and uncoated bars. The opposite is true for the predictions provided by the Orangun, Jirsa, and Breen (1977) equation, except for the members with uncoated bars and no transverse reinforcement, which produce a test/prediction ratio of about 1.0 . The relative values produced by the three procedures are not totally unexpected; the design equations are conservative for $f_{s}<60 \mathrm{ksi}(414 \mathrm{MPa}$ ) (as is the case in the current study) and become progressively more conservative the lower the failure stress (Darwin et al. 1992), while the Orangun, Jirsa, and Breen equation is a best fit of data that takes into account the nonproportional relationship between $f_{s}$ and $l_{s}$ [Eq. (4)]. Overall, the ratios of test strength to predicted strength obtained from the Orangun, Jirsa, Breen equation are more consistent and exhibit significantly less scatter than do similar ratios obtained from the AASHTO and ACI provisions. 


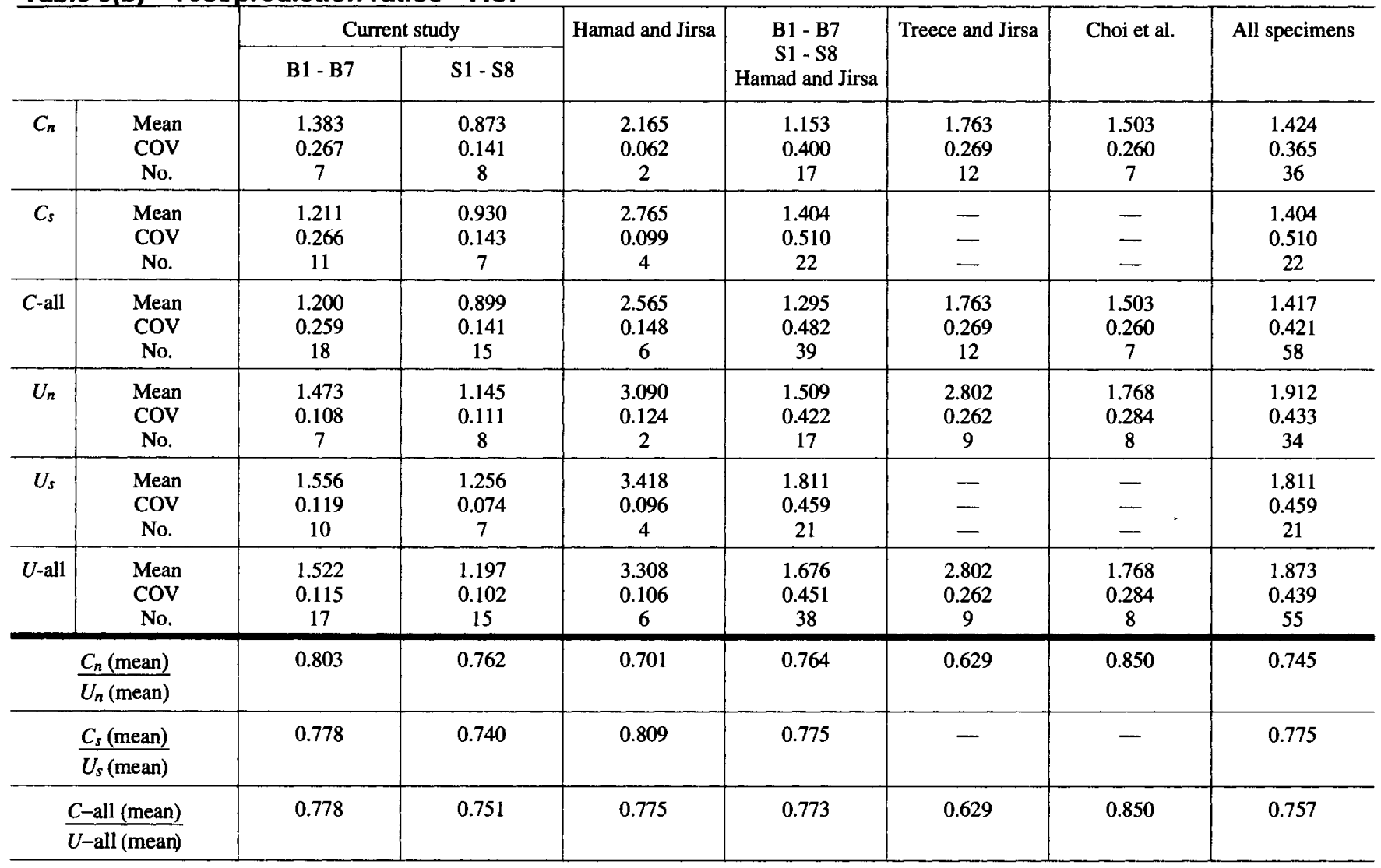

COV $=$ coefficient of variation; No. = number of specimens; $C=$ coated bars; $U=$ uncoated bars; $n=$ no stimups within splice length; $s=$ stimups within splice length.

The ACI (1989) provisions, on average, provide less conservative estimates of splice strength than do the AASHTO (1989) provisions. However, comparisons with the AASHTO provisions exhibit less scatter, as demonstrated by generally lower coefficients of variation. For example, for all uncoatedbar specimens, the ACI provisions produce a mean test/prediction ratio of 1.87 and a COV of 0.439 , compared to a mean test/prediction ratio of 2.04 and a COV of 0.303 for AASHTO.

The highest test/prediction ratios for the two sets of design provisions are obtained from the tests by Hamad and Jirsa (1990) and Treece and Jirsa (1987, 1989). All of the specimens tested by Hamad and most of those tested by Treece contained top reinforcement. Thus, applying 1/1.4 (AASHTO 1989 ) and the $1 / 1.3$ (ACI 1989) factors to calculate $f_{s}$ has a significant impact on reducing the predicted splice strength. These specimens also had low covers and/or bar spacings, which require the use of additional factors under the provisions of Section 12.2.3 of ACI 318-89 that further reduce the predicted strength.

The lowest test/prediction ratios based on the AASHTO and $\mathrm{ACI}$ provisions for uncoated bars, 1.51 and 1.20 , respectively, are obtained for the specimens in Groups S1 through S8. This may be due to the fact that, although these specimens did not contain top reinforcement, they did contain top-cast (upper surface) reinforcement. As demonstrated by Brettmann, Darwin, and Donahey (1986), significantly reduced bond strength can occur for upper surface bars, even if less than 12 in. $(305 \mathrm{~mm})$ of fresh concrete is placed below the bars.

AASHTO-For the combined (B1-B7, S1-S8, Hamad and Jirsa) results, the mean test/prediction ratios for the AASHTO (1989) provisions for members with coated reinforcement are 1.30 for members without stirrups and 1.53 for members with stirrups. Adding the results of Treece and Jirsa (1987, 1989) and Choi et al. (1990a, 1991), the ratio is 1.50 for all coated-bar splices without stirrups (Treece and Jirsa and Choi et al. did not test beams with stirrups). These values compare to mean test/prediction ratios for the combined results (B1B7, S1-S8, Hamad and Jirsa) for splices with uncoated bars, 1.78 for members without stirrups, and 2.0 for members with stirrups. The average for all specimens with uncoated bars and no stirrups is 2.03 .

$A C I-T h e$ test/prediction ratios for the ACI $318-89$ provisions for bars with coated reinforcement are 1.15 and 1.40 for the combined (B1-B7, S1-S8, Hamad and Jirsa) results for members without and with stirrups, respectively. For uncoated bars, the ratios are 1.51 and 1.81 for members without and with stirrups, respectively. For all specimens without stirrups, the ratios for coated and uncoated bars are 1.42 and 1.91 , respectively.

Orangun, Jirsa, and Breen-Of the three procedures, the Orangun, Jirsa, and Breen (1977) equation consistently provides the most accurate predictions for the uncoated bar specimens without stirrups. However, Eq. (4) significantly overpredicts the strength provided by transverse reinforcement for the specimens analyzed in this study. For the com- 
Table 3(c)-Test/prediction ratios-Orangun, Jirsa, and Breen

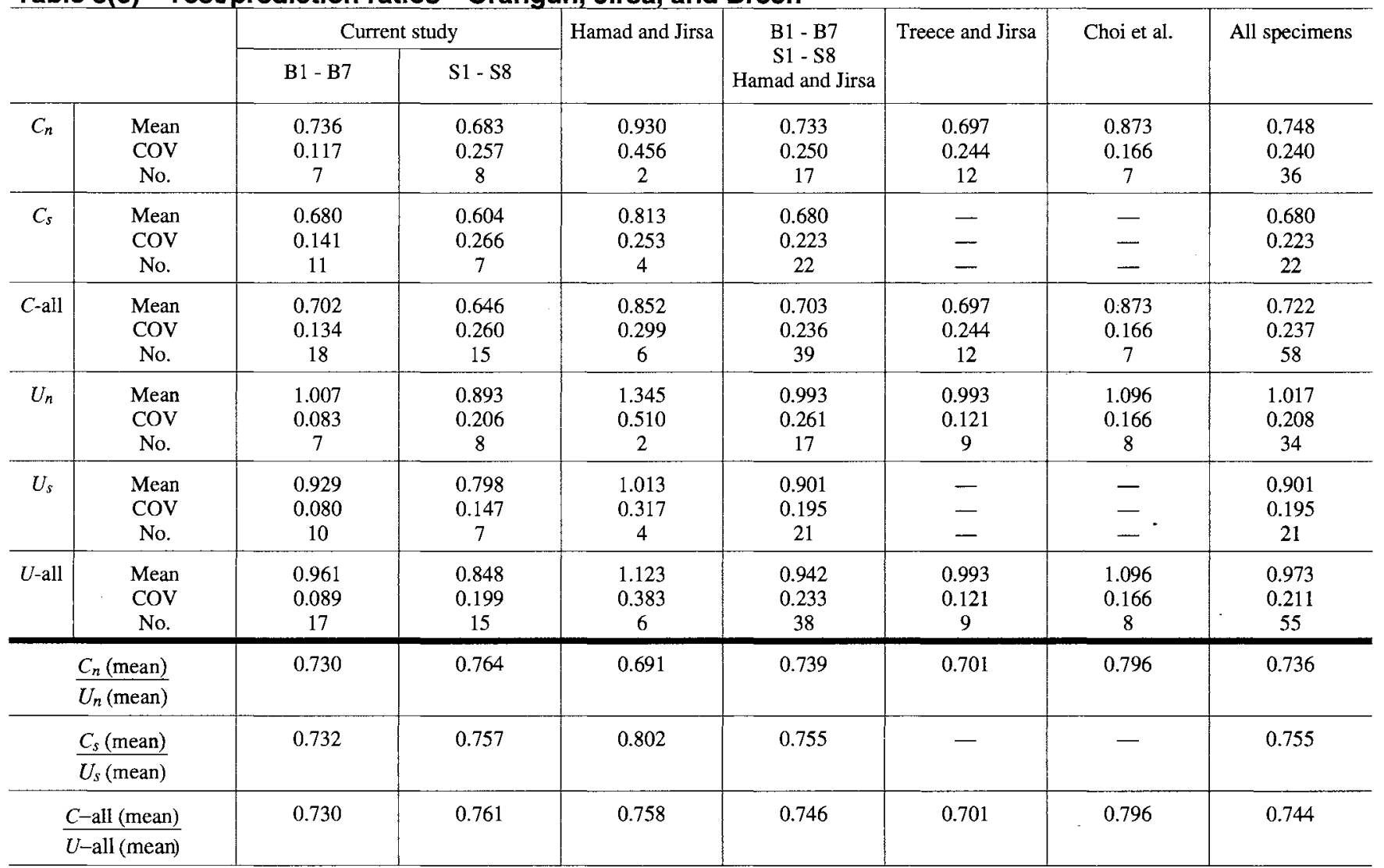

COV = coefficient of variation; No. = number of specimens; $C=$ coated bars; $U=$ uncoated bars; $n=$ no stirrups within splice length; $s=$ stirnups within splice length.

bined (B1-B7, S1-S8, Hamad and Jirsa) results, the mean test/prediction ratios for coated bar specimens are 0.73 and 0.68 for members without and with stirrups, respectively. For members with uncoated bars, the corresponding ratios are 0.99 and 0.90 , respectively. Adding the results from Treece and Jirsa $(1987,1989)$ and Choi et al. $(1990,1991)$, the ratios for members without stirrups are 0.75 and 1.02 for coated and uncoated bar specimens, respectively.

$\mathrm{C} / \mathrm{U}$ ratios - - The test/prediction ratios in Tables 3(a) through (c) for coated and uncoated bars are combined to obtain $C / U$ ratios that are also presented in those tables.

The $C / U$ ratios presented in Table 3(c), based on comparison with the Orangun, Jirsa, and Breen equation, are theoretically the most useful since, for uncoated bars, Eq. (4) gives a far better prediction of splice strength than do the design equations. However, for application to design, it makes more sense to consider the $C / U$ ratios calculated from the test/prediction ratios obtained with the design equations, assuming that the safety and accuracy of the design equations for uncoated bar splices are considered satisfactory. From a practical point of view, a choice is not necessary, since the values of $C / U$ obtained from the mean test/prediction ratios in Tables 3(a) through (c) are nearly identical for each category of comparison.

For comparison with the AASHTO (1989) provisions, the results of the current study, combined with those of Hamad and Jirsa (1990), provide $C / U$ values of 0.73 and 0.75 for members without and with stirrups, respectively. For comparison with the $\mathrm{ACI}$ (1989) provisions, the respective values are 0.76 and 0.78 , while, in comparison to the Orangun, Jirsa, and Breen (1977) equation, the respective values are 0.74 and 0.76. Adding the results of Treece and Jirsa $(1987,1989)$ and Choi et al. $(1990,1991)$ to the other studies provides $C / U$ values of $0.74,0.75$, and 0.74 , respectively, for the AASHTO, ACI, and Orangun, Jirsa, and Breen comparisons for members without stirrups. These values differ significantly from the value of 0.66 that led Treece and Jirsa (1987, 1989) to recommend the 1.5 epoxy-coated bar development length modification factor that is now in use in the 1989 AASHTO Bridge Specifications and ACI 318-89. The higher values of $C / U$ obtained in the current analysis are based on over five times the number of tests used to develop the original recommendations.

\section{DESIGN RECOMMENDATIONS}

The test results and analyses presented in this report demonstrate that 1) transverse reinforcement increases the splice strength of coated as well as uncoated bars and 2) the current provisions for epoxy-coated reinforcement are overconservative for most applications.

\section{Basic recommendation}

The analysis presented in the previous sections illustrates that a $C / U$ ratio of 0.74 represents the effect of epoxy coating on splice strength conservatively. Thus, it may be reasoned that the inverse of $0.74,1.35$, could serve as a conservative epoxy-coated bar development length modification factor, 
Table 4(a)-Test/prediction ratios with proposed epoxy-coated bar development length modification factors*-AASHTO

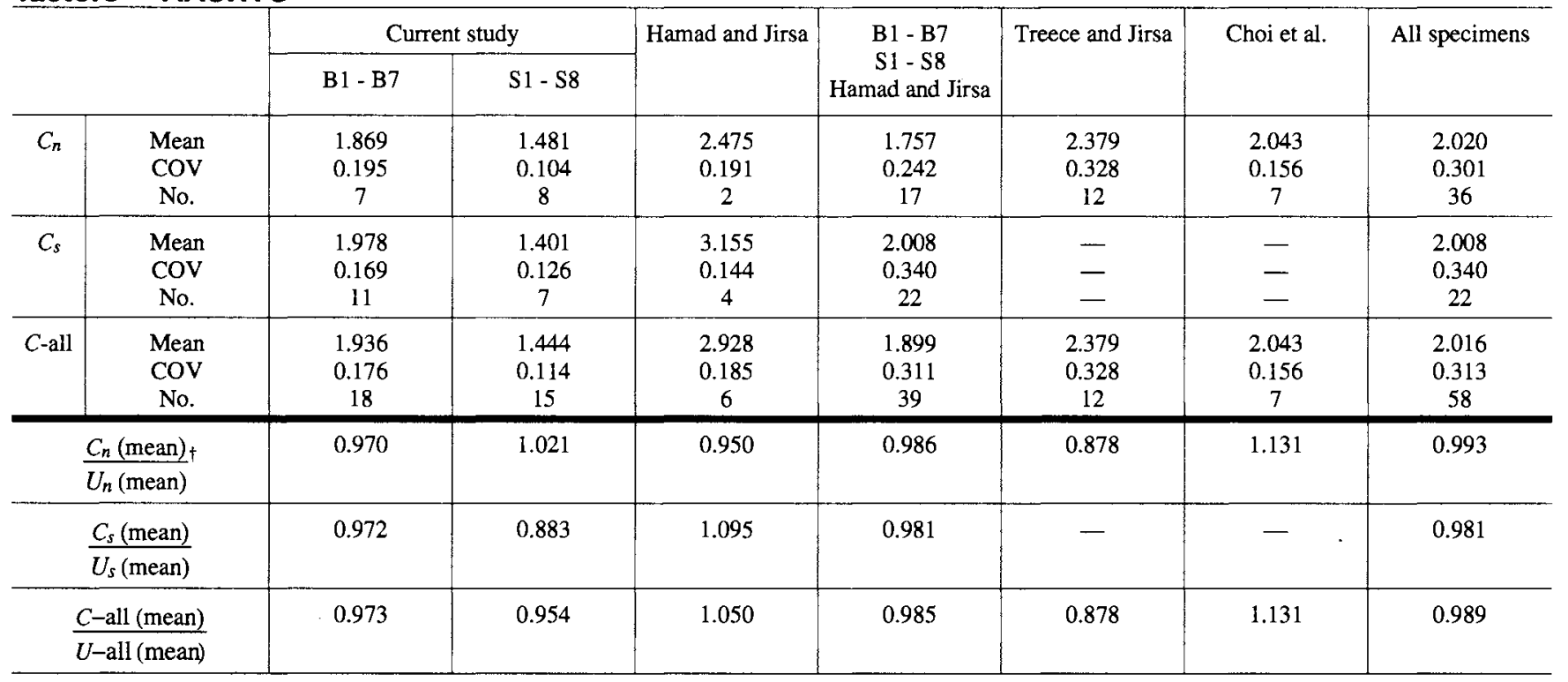

*Modification factor $=1.20$ for $K_{t r}>3.0 ; 1.35$ otherwise.

† See Table 3(a) for uncoated bar data.

$\mathrm{COV}=$ coefficient of variation; No. $=$ number of specimens; $C=$ coated bars; $U=$ uncoated bars; $n=$ no stimups within splice length; $s=$ stirrups within splice length.

whether the anchored bar is confined with transverse reinforcement or not.

It might be asked: Why not use the minimum value of $C / U$ obtained in tests rather than an average value? Isn't the minimum value needed for safety? The answer is that the bond strengths provided by epoxy-coated bars exhibit no greater scatter than those provided by uncoated bars. Thus, if the engineering community can accept the scatter that is inherent in the bond strength of uncoated bars, comparisons should be made based on average strengths rather than minimum ratios of coated to uncoated bar-bond strengths.

\section{Bars with transverse reinforcement}

The provisions of ACI 318-89 and the Orangun, Jirsa, and Breen (1977) equation account for improvements in bond strength provided by transverse reinforcement. Thus, when using either the ACI 318-89 provisions or the Orangun, Jirsa, and Breen equation, a single development length modification factor is satisfactory in all cases. However, the AASHTO Bridge Specifications do not take advantage of improvements in bond strength provided by transverse reinforcement. Therefore, it would be possible to allow the use of a reduced development length modification factor in conjunction with the AASHTO Bridge Specifications, as they are currently framed, without resulting in designs that are any less safe than are provided by uncoated bars without transverse reinforcement.

Based on the analysis of $C / U_{n}$ versus $K_{t r}$, it appears that a modification factor of 1.20 would be reasonable for members with transverse reinforcement, providing a $K_{t r}$ value of at least 3.0. As mentioned earlier, an analysis of specimens with $K_{t r} \leq 3.0$ shows that a development length modification factor of 1.15 could be justified at $K_{t r}=3.0$, but that a more conservative value appears to be justified without some additional test results. Presumably, development length modification factors between 1.35 and 1.2 could be used for values of $K_{t r}$ between 0 and 3.0. However, it is highly doubtful that a variable factor would be practical, based on the extra design effort required. If adopted, the 1.20 development length modification factor would be applied most effectively to the inner layer of reinforcing bars in slabs and walls.

For the purpose of calculating the value of $K_{t r}$, the definitions presented with Eq. (1) and illustrated in Fig. 4 for $A_{t r}$ should be used. To determine when the transverse reinforcement intercepts a crack plane that involves multiple bars on splices, as indicated in Fig. 4(a), or a single bar or splice, as indicated in Fig. 4(b), the definition shown in Fig. 4(b) should be used for bars with a lateral center-to-center spacing of 6 in. or greater. The definition shown in Fig. 4(a) applies for closer spacings.

\section{Application of the proposed provisions}

The application of the proposed provisions is demonstrated in Tables 4(a) through (c). In Tables 4(a) and (b), the AASHTO (1989) and ACI (1989) provisions are modified to include the recommended epoxy-coated bar modification factors. A 1.35 factor is applied in all cases for ACI 318-89 and to all comparisons, except Groups S1 through S8, for the AASHTO provisions; a factor of 1.20 is used for Groups S1 through S8. Applying the proposed factors increases the test/prediction ratios for the specimens containing coated bars to values that are very close to those obtained for the specimens containing uncoated bars. For example, for the modified AASHTO (1989) provisions, the test/theory ratio for splices with coated bars without stirrups increases to 2.02, compared to a value of 2.03 for splices with uncoated bars without stirrups. For splices with stirrups, the ratio increases 
Table 4(b)-Test/prediction ratios with proposed epoxy-coated bar development length modification factor*-ACI

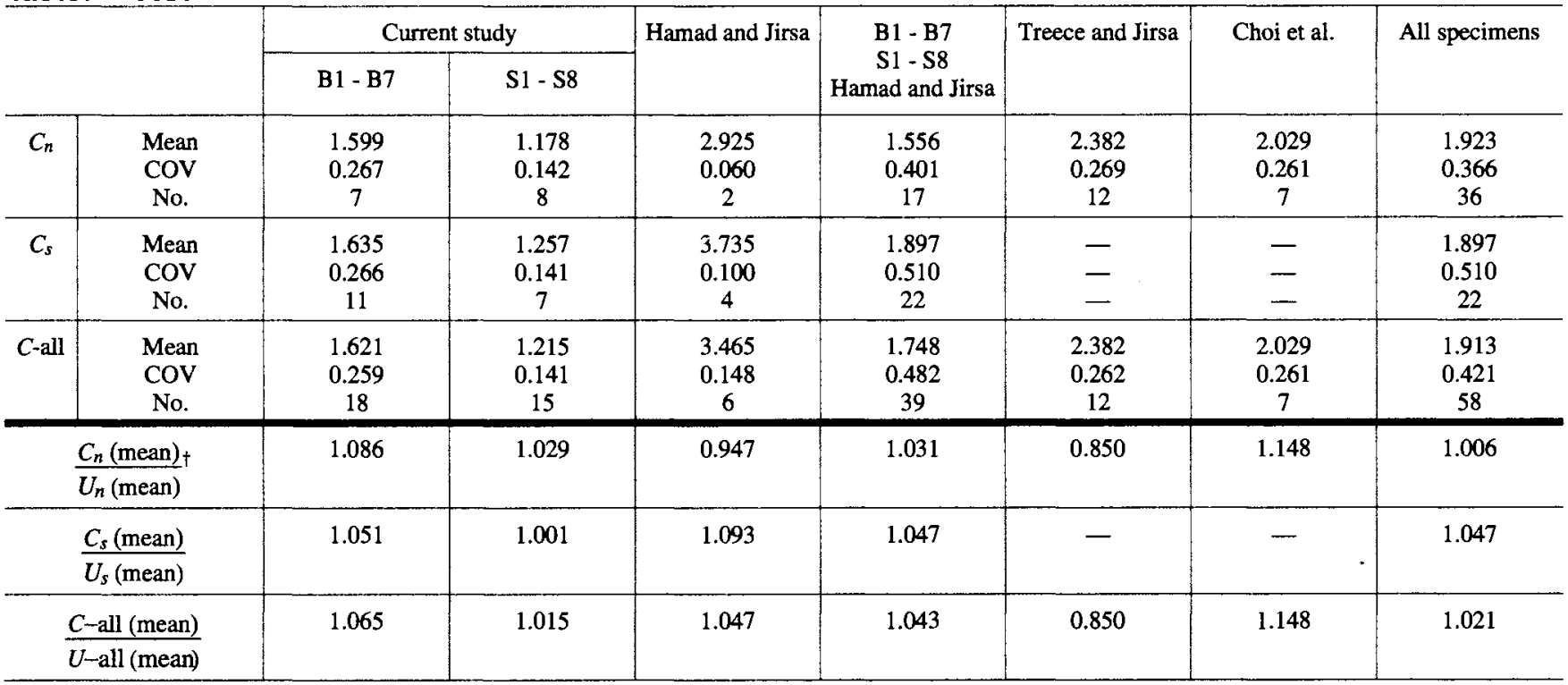

*Modification factor $=1.35$.

tSee Table 3(b) for uncoated bar data

COV = coefficient of variation; No. = number of specimens; $C=$ coated bars; $U=$ uncoated bars; $n=$ no stirrups within splice length; $s=$ stirrups within splice length.

Table 4(c)-Test/prediction ratios with proposed epoxy-coated bar development length modification factor*-Orangun, Jirsa, and Breen

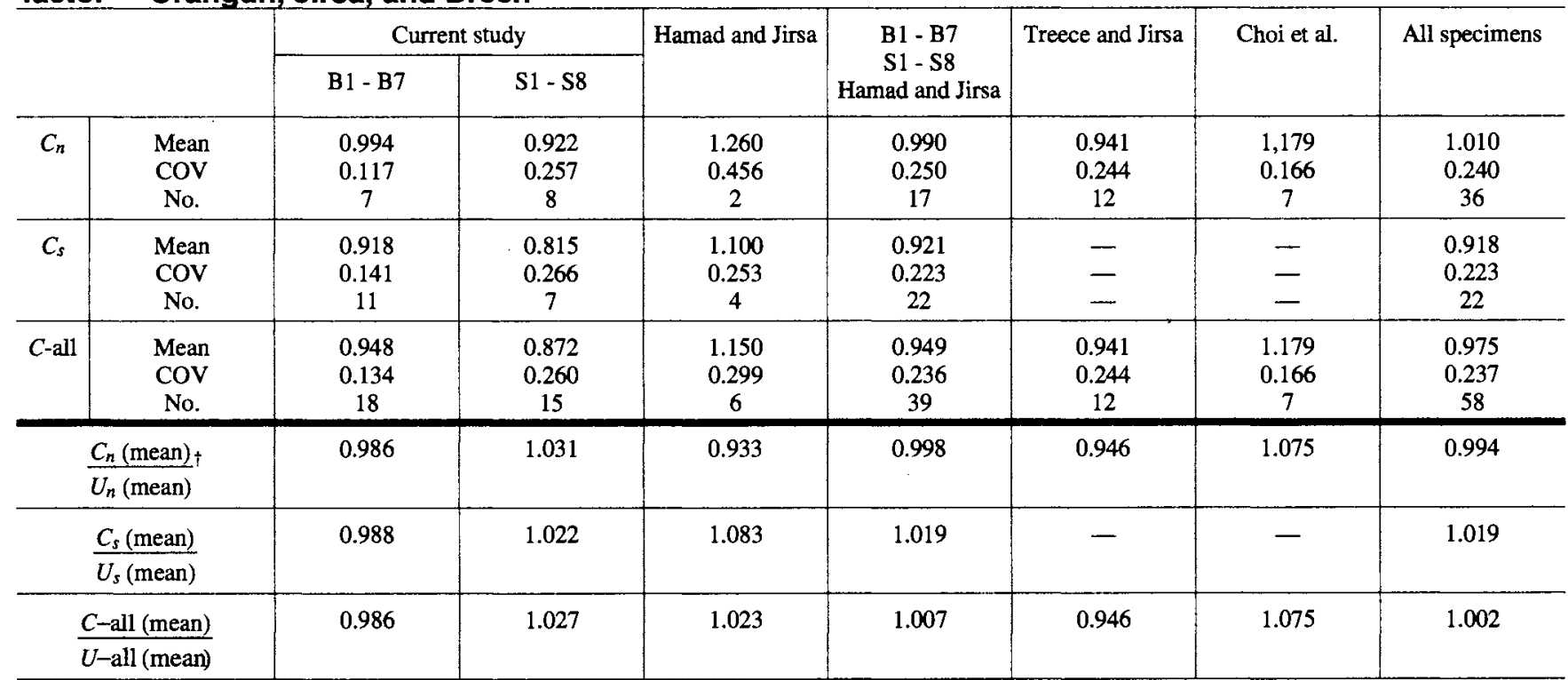

*Modification factor $=1.35$.

tSee Table 3(c) for uncoated bar data.

$\operatorname{COV}=$ coefficient of variation; No. = number of specimens; $C=$ coated bars; $U=$ uncoated bars; $n=$ no stirrups within splice length; $s=$ stirnups within splice length.

to 2.01 for coated bars compared to 2.05 for uncoated bars. Similar improvements are made for ACI 318-89.

Application of the 1.35 factor with the Orangun, Jirsa, and Breen equation [Table 4(c)] produces values of test/prediction ratios that also are very similar for coated and uncoated bars.

\section{Bars with high cover and spacing}

Recent work by Hadje-Ghaffari, Darwin, and McCabe (1991) indicates that the 1.20 factor (ACI 1989) is justified by test results, but that the 1.15 factor (AASHTO 1989) is slightly unconservative for epoxy-coated bars with 3 bar diameters or more of concrete cover and 6 bar diameters or more of clear spacing between bars. This point will be addressed at greater length in the next paper in this series.

\section{CONCLUSIONS}

Based on tests of 65 beam and slab splice specimens and the analysis of those specimens plus an additional 48 specimens from earlier studies, it may be concluded that: 
1. Epoxy coatings significantly reduce the splice strength of deformed reinforcing bars in concrete. However, the extent of the reduction is less than that used to select the development length modification factors in the 1989 ACI Building Code and 1989 AASHTO Bridge Specifications.

2. The percentage decrease in splice strength caused by epoxy coatings is independent of the degree of transverse reinforcement.

3. Transverse reinforcement improves the strength of splices containing both coated and uncoated bars. The percentage increase in strength is approximately the same for both coated and uncoated bars for equal amounts of transverse reinforcement.

4. The added strength provided by transverse reinforcement allows the use of a reduced epoxy-coated bar development length modification factor if adequate transverse reinforcement is provided and the provisions do not otherwise take into account the beneficial effect of transverse reinforcement on development and splice strength.

5. A maximum epoxy-coated bar development length modification factor of 1.35 is applicable for use in the ACI Building Code. A maximum factor of 1.35 is also applicable for use in the AASHTO Bridge Specifications for bars with transverse reinforcement providing values of $K_{t r}<3.0$. A factor of 1.20 is applicable for use with the AASHTO Bridge Specifications for bars with transverse reinforcement providing values of $K_{t r} \geq 3.0$.

\section{ACKNOWLEDGMENTS}

Major funding for this research was provided by the Kansas Department of Transportation. Reinforcing steel was supplied by Chaparral Steel Company, North Star Steel Company, and Structural Metals, Inc. The epoxy coating, 3M Scotchkote 213, was applied by ABC Coating, Inc. and Simcote, Inc. Form release agent for the project was supplied by Nox-Crete, Inc.

\section{REFERENCES}

AASHTO Highway Sub-Committee on Bridges and Structures (1989), Standard Specification for Highway Bridges, 14th ed., American Association of State Highway and Transportation Officials, Washington, DC.

ACI Committee 318 (1983), "Building Code Requirements for Reinforced Concrete (ACI 318-83)," American Concrete Institute, Detroit, 111 pp.

ACI Committee 318 (1989), "Building Code Requirements for Reinforced Concrete and Commentary (ACI 318-89/ACI 318R-89)," American Concrete Institute, Detroit, 353 pp.

ASTM (1989), "Standard Specification for Deformed and Plain BilletSteel Bars for Concrete Reinforcement," (ASTM A 615-89), 1989 Annual Book of ASTM Standards, V. 1.04, ASTM, Philadelphia, pp. 388-391.

ASTM (1989), "Standard Specification for Epoxy-Coated Reinforcing Steel Bars," (ASTM A 775/A775M-89a) 1989 Annual Book for ASTM Standards, V. 1.04, ASTM, Philadelphia, pp. 555-559.
Brettmann, Barrie B; Darwin, David; and Donahey, Rex C. (1986), "Bond of Reinforcement to Superplasticized Concrete," ACI Journal. Proceedings V. 83, No. 1, Jan.-Feb., pp. 98-107.

Choi, Oan Chul; Darwin, David; and McCabe, Steven L. (1990), "Bond Strength of Epoxy-Coated Reinforcement to Concrete," SM Report No. 25, University of Kansas Center for Research, Lawrence, July, 217 pp.

Choi, Oan Chul; Hadje-Ghaffari, Hossain; Darwin, David; and McCabe, Steven L. (1990), "Bond of Epoxy-Coated Reinforcement to Concrete: Bar Parameters, SL Report 90-1, University of Kansas Center for Research, Lawrence, Jan., 43 pp.

Choi, Oan Chul; Hadje-Ghaffari, Hossain; Darwin, David; and McCabe, Steven L. (1991). "Bond of Epoxy-Coated Reinforcement: Bar Parameters," ACl Materials Journal, V. 88, No. 2, Mar.-Apr., pp. 207-217.

Cleary, Douglas B., and Ramirez, Julio A. (1989), "Bond of Epoxy Coated Reinforcing Steel in Concrete Bridge Decks," Joint Highway Research Project Information Report, JHRP 89-7, Purdue University, 127 pp.

Cleary, Douglas B., and Ramirez, Julio A. (1991), "Bond of EpoxyCoated Reinforcement," ACI Materials Journal, V. 88, No. 2, Mar.-Apr., pp. 146-149.

Darwin, David; McCabe, Steven L.; and Choi, Oan Chul (1990), "Evaluation of Bond Performance of Epoxy-Coated Reinforcing Steel Using Nonlinear Finite Element Analysis," Proceedings, First ASCE Materials Engineering Congress, Denver, Aug., V. 1, pp. 135-144.

Darwin, David; McCabe, Steven L.; Hadje-Ghaffari, Hossain; and Choi, Oan Chul (1990), "Bond Strength of Epoxy-Coated Reinforcement to Concrete-An Update," Proceedings, First ASCE Materials Engineering Congress, Denver, Aug., V. 1, pp. 115-124.

Darwin, David; McCabe, Steven L.; Idun, Emmanuel K.; and Schoenekase, Steven P. (1992), "Development Length Criteria: Bars without Transverse Reinforcement," SL Report 92-1, University of Kansas Center for Research, Lawrence, Apr., 62 pp.

Draper, N. R., and Smith, H. (1981), Applied Regression Analysis, 2nd ed., John Wiley \& Sons, Inc., pp. 241-249.

Hadje-Ghaffari, Hossain; Darwin, David; and McCabe, Steven L. (1991), "Effects of Epoxy Coating on Bond of Reinforcing Steel to Concrete," SM Report No. 28, University of Kansas Center for Research, Lawrence, July, $288 \mathrm{pp}$.

Hamad, Bilal S., and Jirsa, James O. (1990), "Influence of Epoxy Coating on Stress Transfer from Steel to Concrete," Proceedings, First ASCE Materials Engineering Congress, Denver, Aug., pp. 125-134.

Hester, Cynthia J.; Salamizavaregh, Shahin; Darwin, David; and McCabe, Steven L. (1991), "Bond of Epoxy-Coated Reinforcement to Concrete: Splices," SL Report 91-1, University of Kansas Center for Research, Lawrence, May, $66 \mathrm{pp}$.

Johnston, David W., and Zia, Paul. (1982), "Bond Characteristics of Epoxy Coated Reinforcing Bars," Report No. FHWA-NC-82-002, Center for Transportation Engineering Studies, Civil Engineering Department, North Carolina State University, Raleigh, 163 pp.

Orangun, C. O.; Jirsa, J. O.; and Breen, J. E. (1977), "Reevaluation of Test Data on Development Length and Splices," ACI JourNaL, Proceedings V. 74, No. 3, Mar., pp. 114-122.

Treece, Robert A., and Jirsa, James O. (1987), "Bond Strength of Epoxy-Coated Reinforcing Bars," PMFSEL Report No. 87-1, Phil M. Ferguson Structural Engineering Laboratory, University of Texas at Austin, Jan., 85 Pp.

Treece, Robert A., and Jirsa, James O. (1989), "Bond Strength of Epoxy-Coated Reinforcing Bars," ACI Materials Journal, V. 86, No. 2, Mar.Apr., pp. 167-174. 


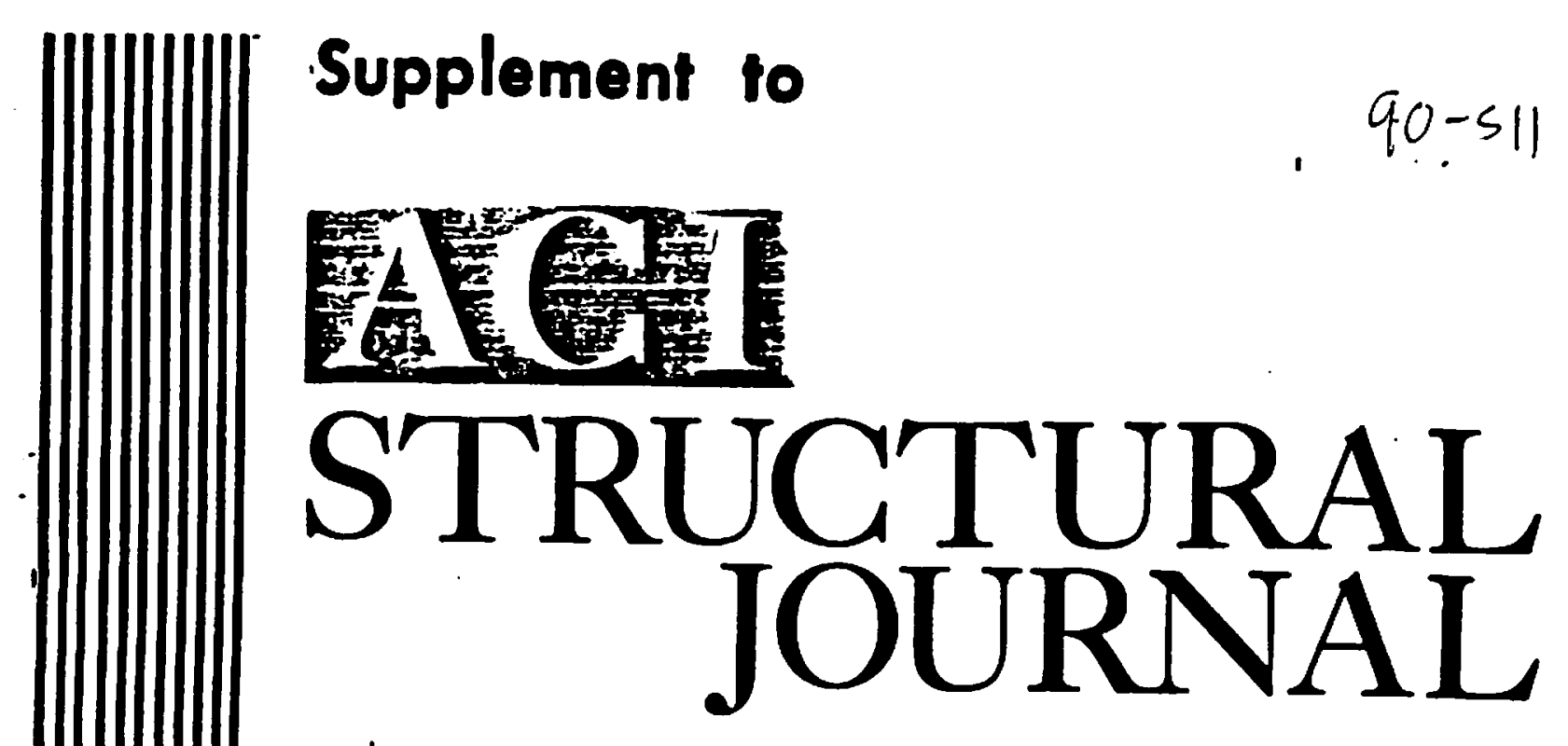

"Bond of Epoxy-Coated Reinforcement-Splices by Cynthin J. Hester etal, ACI Structura! Journal , V. 90 , No. 1 , pp. $89-102$ 
$90-511$

\author{
Appendixes for \\ BOND OF EPOXY-COATED REINFORCEMENT: SPLICES \\ by Cynthia J. Hester, Shahin Salamizavaregh, \\ David Darwin and Steven L. McCabe
}


Appendlx A

Average test bar data

\begin{tabular}{|c|c|c|c|c|c|c|c|c|c|}
\hline $\begin{array}{l}\text { Bar } \\
\text { slze }\end{array}$ & $\begin{array}{l}\text { Def. } \\
\text { Pactern }\end{array}$ & $\begin{array}{l}\text { Yleld } \\
\text { str. }\end{array}$ & $\begin{array}{l}\text { Def. } \\
\text { spacing }\end{array}$ & $\begin{array}{l}\text { Def } \\
\text { Helght } 6\end{array}$ & $\begin{array}{l}\text { Def. } \\
\text { Gap }\end{array}$ & $\begin{array}{l}\text { Def. } \\
\text { Angle }\end{array}$ & $\begin{array}{l}\text { Bearing } \\
\text { Area } \\
\text { per } \\
\text { Inch } \\
\text { (1n.) }\end{array}$ & $\begin{array}{c}\text { Related } \\
\text { Rib } \\
\text { Area + }\end{array}$ & $\begin{array}{l}\text { Bearlng } \\
\text { Area } \\
\text { Rat 10 } \\
(1 n .-1)\end{array}$ \\
\hline$=====0$ & 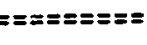 & $===\Xi==$ & $==\Omega==\Omega=\Omega=$ & 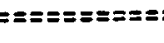 & $===\pi=x$ & $====\Omega==$ & $==x==x=\pi=$ & $====0= \pm==$ & 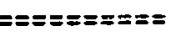 \\
\hline 3 & $\mathbf{s}$ & $6 B .9$ & 0.245 & 0.017 & 0.088 & 90 & $0.05 B$ & 0.049 & 0.526 \\
\hline 3 & c & 54.1 & 0.249 & 0.019 & 0.087 & 60 & 0.058 & 0.049 & 0.533 \\
\hline 3 & $\mathbf{N}$ & 77.3 & 0.244 & 0.019 & 0.100 & 70 & 0.069 & 0.059 & 0.630 \\
\hline 5 & C & 72.3 & 0.413 & 0.041 & 0.116 & 60 & 0.151 & 0.077 & 0.486 \\
\hline 6 & $\mathbf{s}$ & 69.5 & 0.484 & 0.042 & 0.125 & 90 & 0.165 & 0.070 & 0.375 \\
\hline 6 & c & 72.4 & 0.479 & 0.049 & 0.168 & 60 & 0.179 & 0.076 & 0.406 \\
\hline B & $\mathbf{s}$ & 71.1 & 0.667 & 0.055 & 0.145 & 90 & 0.219 & 0.070 & 0.277 \\
\hline 8 & C & 69.0 & 0.654 & 0.062 & 0.163 & 60 & 0.222 & 0.071 & 0.281 \\
\hline 8 & $\mathbf{N}$ & 63.8 & 0.604 & 0.060 & 0.100 & 70 & 0.245 & 0.078 & 0.311 \\
\hline
\end{tabular}

a Per ASTM A 615

- Bearing area of the deformatlons divided by the spacing of the deformations. Bearing area based on closely spaced measurements of ribs.

+ The ratio of the bearing area of the deformations to the shearing area becween the deformations (bearing area divided by the nominal perimeter of the bar).

S The ratio of the bearling area of the deformations to the area of the bar (bearing area divided by the nominal area of the bar).

Note: $1 \mathrm{in} .=25.4 \mathrm{~mm} ; 1 \mathrm{ksi}=6.89 \mathrm{MPa}$ 
Appendix B

Concrete Mixture Proportions (Cubic Yard)

\begin{tabular}{|c|c|c|c|c|c|c|}
\hline Group & $\begin{array}{l}\text { Nominal } \\
\text { Strength } \\
\text { (psi) }\end{array}$ & $\begin{array}{l}\text { W/C } \\
\text { Ratio }\end{array}$ & (1b) & (1b) & $\begin{array}{l}\text { Agg } \\
\text { Finet } \\
\text { (1b) }\end{array}$ & $\begin{array}{l}\text { Coarse* } \\
\text { (1b) }\end{array}$ \\
\hline B1-B3 & 6000 & 0.37 & 765 & 281 & 1264 & 1642 \\
\hline B4 & 6000 & 0.36 & 767 & 279 & 1267 & 1646 \\
\hline B5-B6 & 5500 & 0.45 & 615 & 278 & 1421 & 1620 \\
\hline B7, S1-S7 & 5500 & 0.46 & 600 & 275 & 1481 & 1575 \\
\hline s8 & 5500 & 0.40 & 611 & 242 & 1512 & 1607 \\
\hline
\end{tabular}

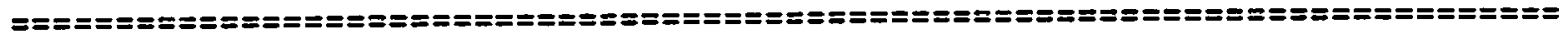

+ Kansas River Sand - Lawrence Sand Co., Lawrence, KS, bulk specific gravity $=2.62$, absorption $=0.58$, finenes modulus $=3.0$.

* Crushed limestone - Hamm's Quarry, Perry, ks, bulk specific gravity = 2.52, absorption $=3.58$, maximum size $=3 / 4$ in., unit weigth $=97.2$ lb/cubic ft.

Note: Air volume ranged from 1.58 to $2.08 ; 11 \mathrm{~b} / \mathrm{YD}^{\wedge} 3=0.5933 \mathrm{~kg} / \mathrm{m}^{\wedge} 3$

\section{Concrete Properties}

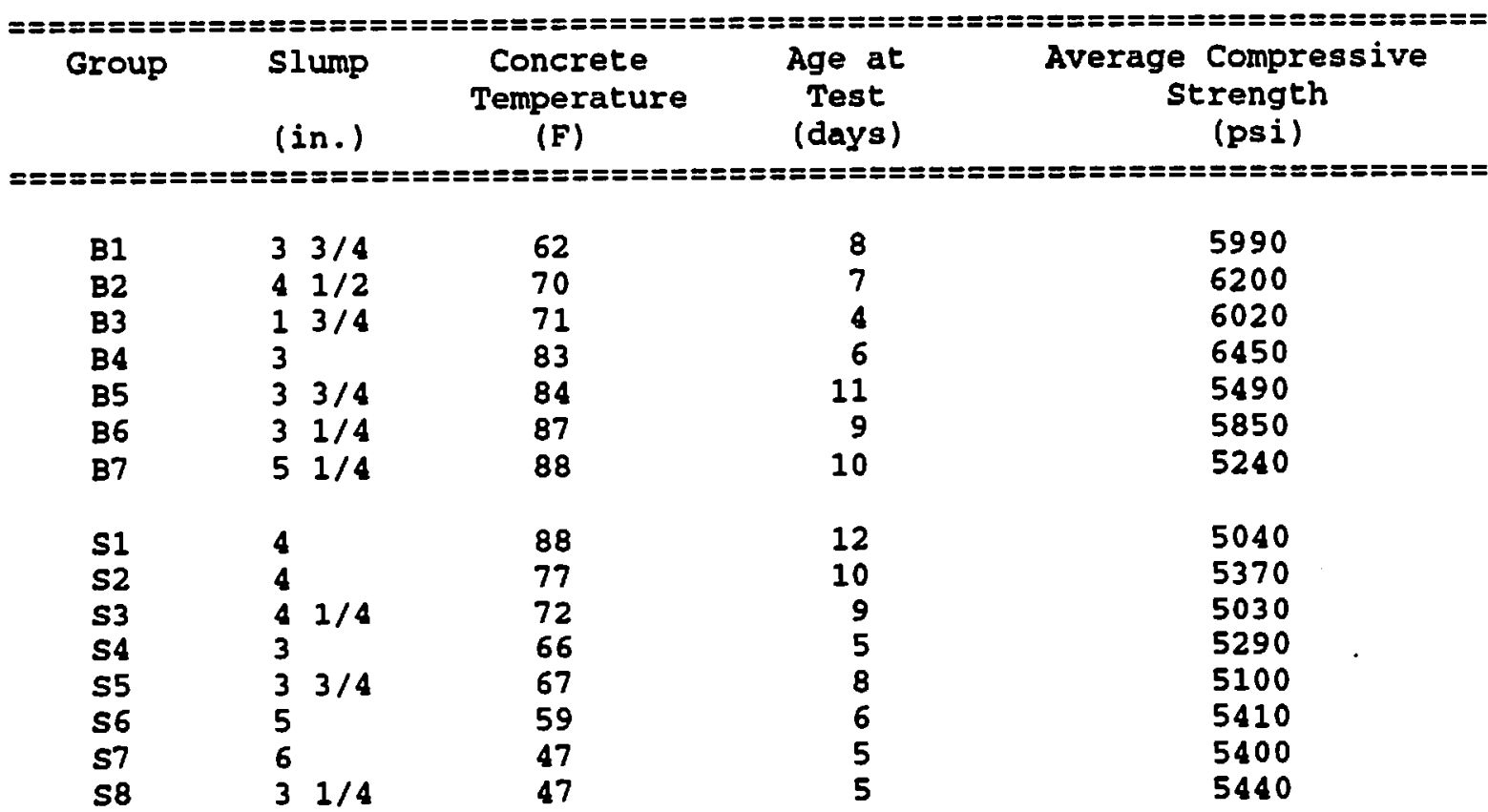

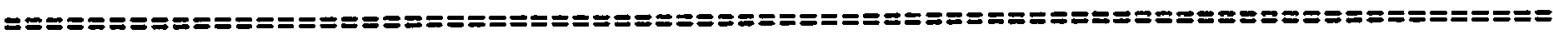

Note: $1 \mathrm{in} .=25.4 \mathrm{~mm} ; 1 \mathrm{psi}=6.89 \mathrm{kPa}$ 
Appendix C

Test data from other studies

Treece \& Jirsa $(1987,1989)$

\begin{tabular}{|c|c|c|c|c|c|c|c|}
\hline $\begin{array}{l}\text { Group } \\
\text { No. }\end{array}$ & $\begin{array}{l}\text { Specimen } \\
\text { Label }\end{array}$ & $\begin{array}{l}\text { No. of } \\
\text { Splices }\end{array}$ & $\begin{array}{l}\text { Avg. } \\
\text { Coat. } \\
\text { Thck. } \\
\text { (mils) }\end{array}$ & $\begin{array}{l}\text { Cover } \\
\text { (1n.) }\end{array}$ & $\begin{array}{l}\text { Conc. } \\
\text { ser. } \\
\text { (ps1) }\end{array}$ & $\begin{array}{l}\text { Ult. } \\
\text { stress } \\
\text { (ksi) }\end{array}$ & $\begin{array}{l}\text { Relacive :* } \\
\text { Strength } \\
\qquad \frac{C}{U}\end{array}$ \\
\hline \multicolumn{8}{|c|}{ 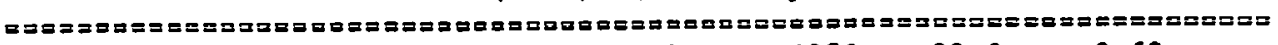 } \\
\hline 1 & $\begin{array}{l}6 D 0-12-0-C \\
6 D 0-12-0-C \\
6 D 0-12-0-U\end{array}$ & $\begin{array}{l}3 \\
3 \\
3\end{array}$ & $\begin{array}{r}10.6 \\
4.8 \\
0.0\end{array}$ & $\begin{array}{l}2 \\
2 \\
2\end{array}$ & 4250 & $\begin{array}{l}33.0 \\
46.2 \\
53.1\end{array}$ & $\begin{array}{c}0.62 \\
0.87 \\
--\end{array}$ \\
\hline 2 & $\begin{array}{l}6 D 0-24-0-C \\
6 D 0-24-0-C \\
6 D 0-24-0-U\end{array}$ & $\begin{array}{l}3 \\
3 \\
3\end{array}$ & $\begin{array}{l}9.0 \\
4.5 \\
0.0\end{array}$ & $\begin{array}{c}7 / 8 \\
3 / 4 \\
1\end{array}$ & 3860 & $\begin{array}{l}44.8 \\
47.9 \\
63.3\end{array}$ & $\begin{array}{l}0.71 \\
0.76 \\
-.\end{array}$ \\
\hline 3 & $\begin{array}{l}11 D 0-36-0-C \\
11 D 0-36-0-C \\
11 D 0-36-0-U\end{array}$ & $\begin{array}{l}3 \\
3 \\
3\end{array}$ & $\begin{array}{l}9.1 \\
5.9 \\
0.0\end{array}$ & $\begin{array}{l}2 \\
2 \\
2\end{array}$ & 5030 & $\begin{array}{l}28.3 \\
30.4 \\
43.3\end{array}$ & $\begin{array}{l}0.65 \\
0.70 \\
=-\end{array}$ \\
\hline 4 & $\begin{array}{l}11 D 0-36-0-C \\
11 D 0-36-0-U\end{array}$ & $\begin{array}{l}3 \\
3\end{array}$ & $\begin{array}{r}11.0 \\
0.0\end{array}$ & $\begin{array}{l}2 \\
2\end{array}$ & 4290 & $\begin{array}{l}24.9 \\
45.9\end{array}$ & $\begin{array}{c}0.54 \\
--\end{array}$ \\
\hline 5 & $\begin{array}{l}6 D 0-16-0-C \\
6 D 0-16-0-U\end{array}$ & $\begin{array}{l}3 \\
3\end{array}$ & $\begin{array}{r}14.0 \\
0.0\end{array}$ & $\begin{array}{l}3 / 4 \\
7 / 8\end{array}$ & 8040 & $\begin{array}{l}35.0 \\
63.3\end{array}$ & $\begin{array}{c}0.55 \\
--\end{array}$ \\
\hline 6 & $\begin{array}{l}11 D 0-1 B-0-C \\
11 D 0-18-0-U\end{array}$ & $\begin{array}{l}3 \\
3\end{array}$ & $\begin{array}{l}7.4 \\
0.0\end{array}$ & $\begin{array}{ll}2 & 1 / 4 \\
2 & 1 / 8\end{array}$ & 8280 & $\begin{array}{l}25.3 \\
40.3\end{array}$ & $\begin{array}{c}0.63 \\
--\end{array}$ \\
\hline 7 & $\begin{array}{l}6 D 0-16-0-C \\
6 D 0-16-0-U\end{array}$ & $\begin{array}{l}3 \\
3\end{array}$ & $\begin{array}{r}10.3 \\
0.0\end{array}$ & $\begin{array}{l}5 / 8 \\
3 / 4\end{array}$ & 12600 & $\begin{array}{l}41.1 \\
63.3\end{array}$ & $\begin{array}{c}0.65 \\
--\end{array}$ \\
\hline 8 & $\begin{array}{l}11 D 0-18-0-C \\
11 D 0-18-0-U\end{array}$ & $\begin{array}{l}3 \\
3\end{array}$ & $\begin{array}{l}9.7 \\
0.0\end{array}$ & $\begin{array}{l}2 \\
2\end{array}$ & 10510 & $\begin{array}{l}33.8 \\
46.9\end{array}$ & $\begin{array}{c}0.72 \\
--\end{array}$ \\
\hline 9 & $\begin{array}{l}11 D 0-18-0-C \\
11 D 0-18-0-U\end{array}$ & $\begin{array}{l}3 \\
3\end{array}$ & $\begin{array}{l}8.7 \\
0.0\end{array}$ & $\begin{array}{l}2 \\
2\end{array}$ & 9600 & $\begin{array}{l}27.5 \\
43.0\end{array}$ & $\begin{array}{c}0.64 \\
--\end{array}$ \\
\hline $\begin{aligned}=s & =s=x \\
& \text { Note }\end{aligned}$ & 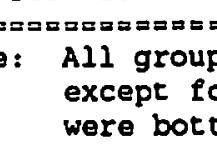 & 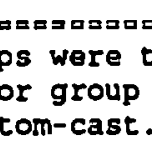 & $\begin{array}{l}= \pm=[== \pm= \\
\text { op-cast } \\
4 \text { and } 9\end{array}$ & which & 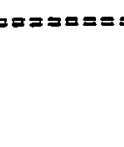 & $\begin{aligned} &=x=x==2= \\
& \text { Mean }=\end{aligned}$ & $\begin{aligned}== & =0=E== \pm=== \\
& 0.67\end{aligned}$ \\
\hline
\end{tabular}

$\bar{C}_{s}=\min (s i d e$ cover, $1 / 2$ clear spacing) $=2$ in. for all members.

Chol et al. (1990a, 1991)

\begin{tabular}{|c|c|c|c|c|c|c|c|}
\hline $\begin{array}{c}\text { Group } \\
\text { No. }\end{array}$ & $\begin{array}{l}\text { Specimen } \\
\text { Label }\end{array}$ & $\begin{array}{l}\text { No. of } \\
\text { Splices }\end{array}$ & $\begin{array}{l}\text { Avg. } \\
\text { Coat. } \\
\text { Thck. } \\
\text { (mils) }\end{array}$ & $\begin{array}{l}\text { Cover } \\
\text { (in.) }\end{array}$ & $\begin{array}{l}\text { Conc. } \\
\text { str. } \\
\text { (psi) }\end{array}$ & $\begin{array}{l}\text { Ult. } \\
\text { Stress } \\
\text { (ksi) }\end{array}$ & $\begin{array}{l}\text { Relative } \\
\text { Strength } \\
\qquad \frac{\mathrm{C}}{\mathrm{U}}\end{array}$ \\
\hline \multicolumn{8}{|c|}{ 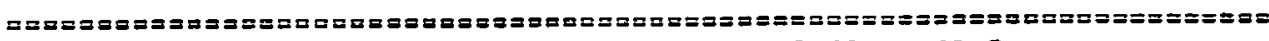 } \\
\hline 1 & $\begin{array}{l}5 N 0-12-0-U \\
5 N 0-12-0-U \\
5 N 0-12-0-C\end{array}$ & $\begin{array}{l}2 \\
3 \\
3\end{array}$ & $\begin{array}{l}0.0 \\
0.0 \\
9.5\end{array}$ & $\begin{array}{l}1 \\
1 \\
1\end{array}$ & 5360 & $\begin{array}{l}62.5 \\
65.3 \\
49.0\end{array}$ & $\begin{array}{c}-- \\
0.75\end{array}$ \\
\hline 2 & $\begin{array}{l}6 S 0-12-0-U \\
6 S 0-12-0-C \\
6 C 0-12-0-U \\
6 C 0-12-0-C\end{array}$ & $\begin{array}{l}2 \\
2 \\
2 \\
2\end{array}$ & $\begin{array}{l}0.0 \\
8.3 \\
0.0 \\
8.8\end{array}$ & $\begin{array}{l}1 \\
1 \\
1 \\
1\end{array}$ & 6010 & $\begin{array}{l}45.8 \\
43.1 \\
51.4 \\
39.3\end{array}$ & $\begin{array}{c}-- \\
0.94 \\
-- \\
0.76\end{array}$ \\
\hline
\end{tabular}


Appendix C (continued)

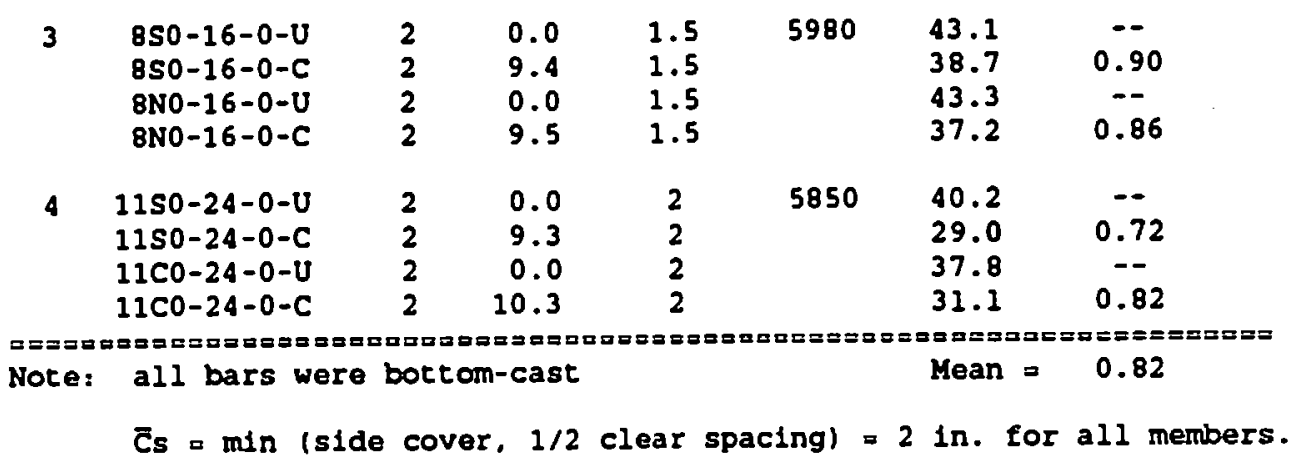

Hamad \& J1rsa (1990)

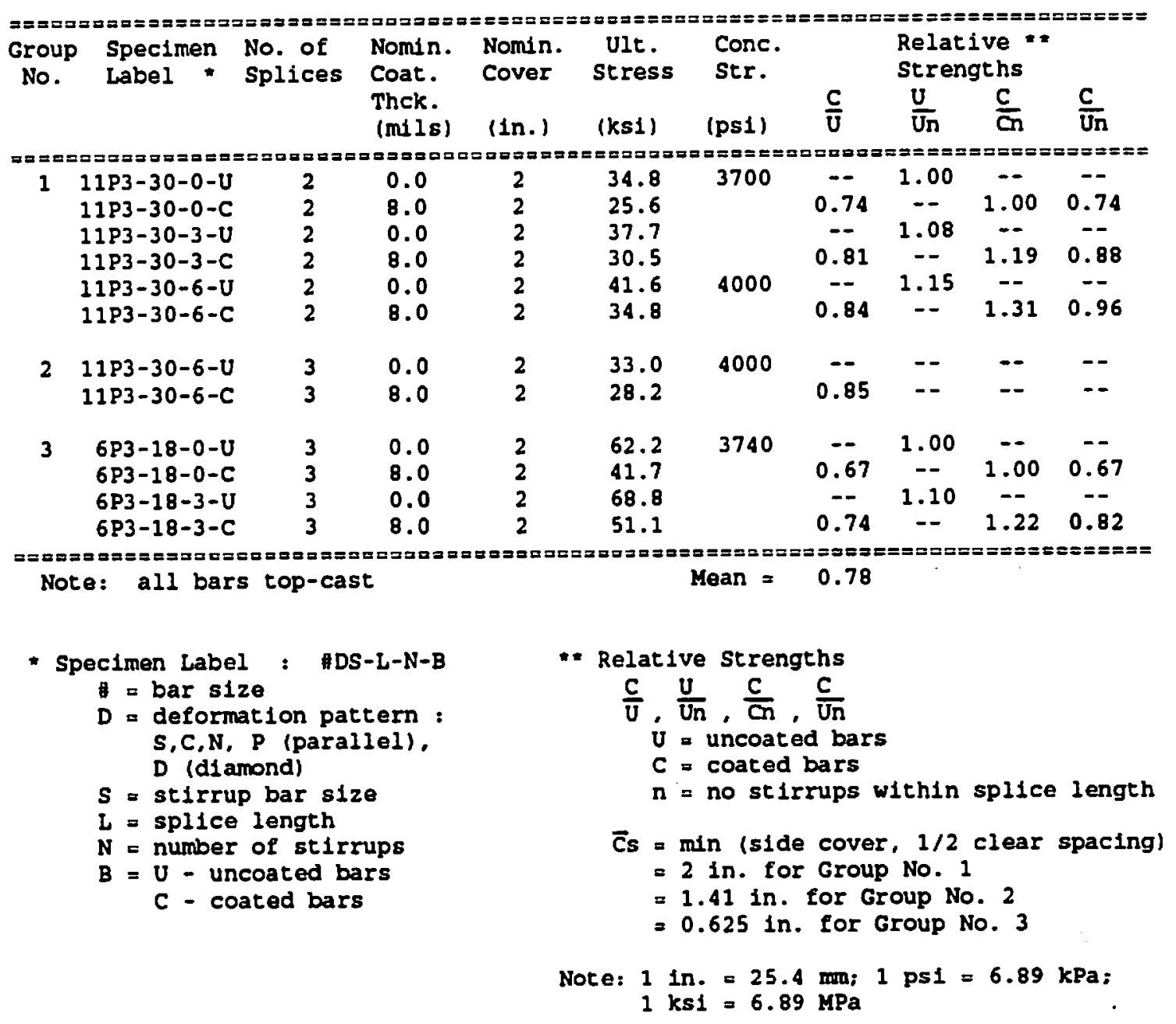


Appendix D1

Test/prediction ratlos for $\mathrm{B} 1-\mathrm{B} 7$ splice tests

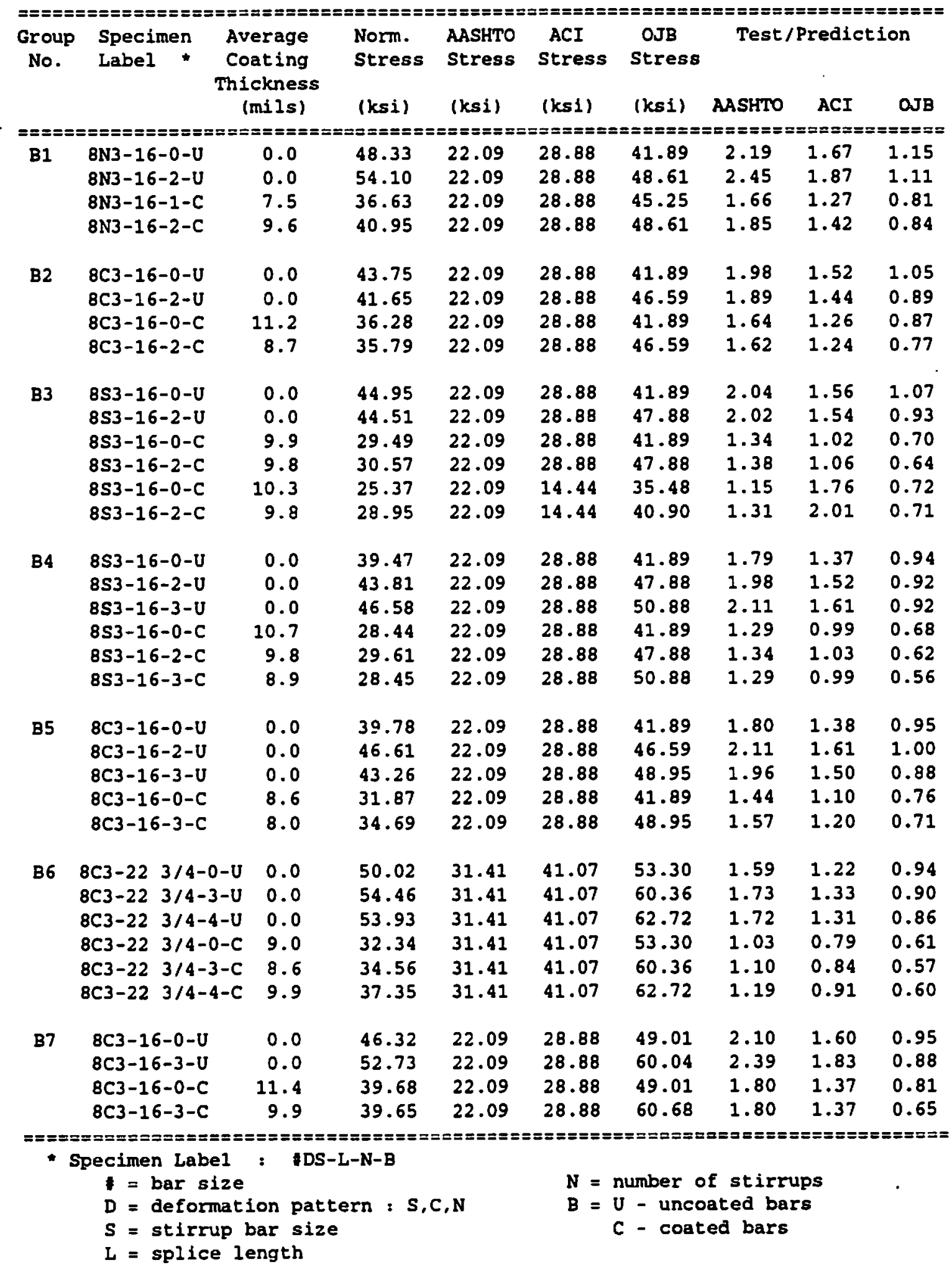

Note: 1 . Norm. Stress $=$ Ult. Stress $\left(5500 / \mathrm{f}^{\prime} \mathrm{C}\right)^{\wedge} 1 / 2$

2. $1 \mathrm{mil}=0.001 \mathrm{in} . ; 1 \mathrm{in}$. $=25.4 \mathrm{~mm} ; 1 \mathrm{ksi}=6.89 \mathrm{MPa}$ 
Appendix D2

Test/prediction ratios for S1-S8 splice tests

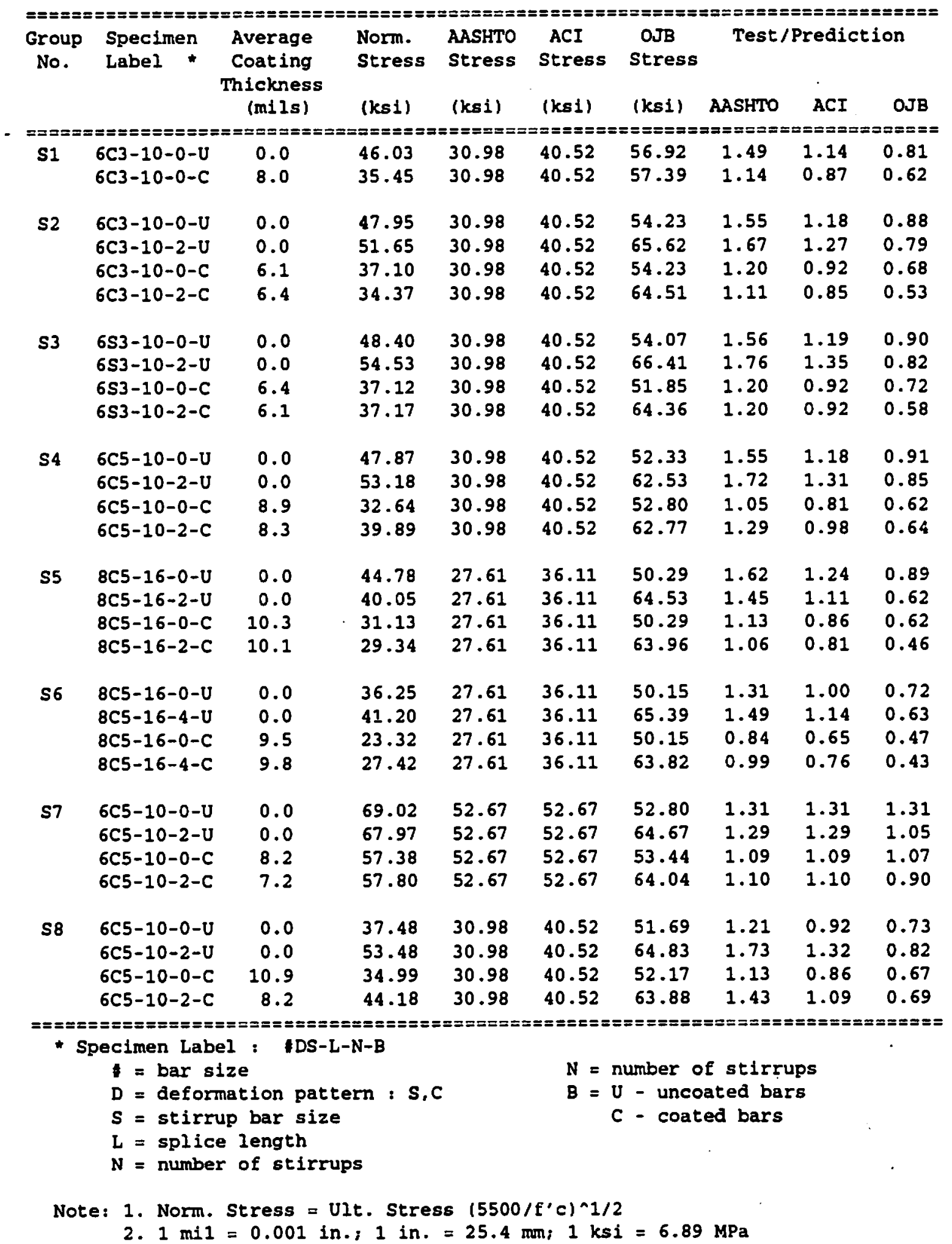




\author{
Appendix D3 \\ Test/prediction ratios for other studies \\ Treece Jirsa (1987, 1989)
}

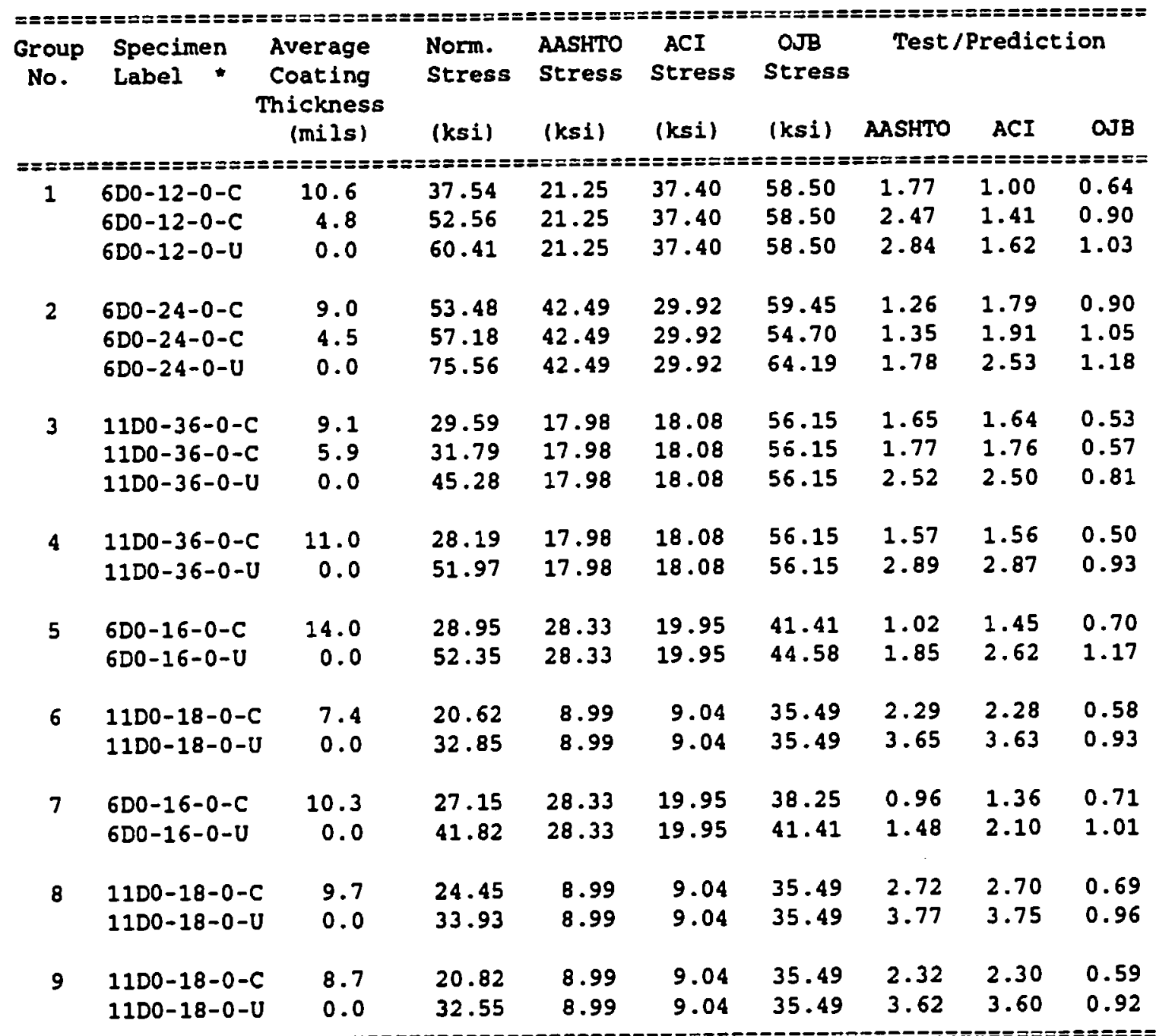

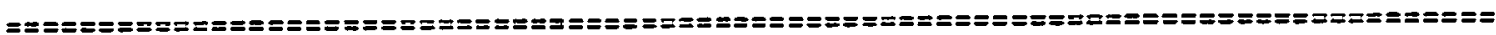

Choi et al. (1990a, 1991)

\begin{tabular}{|c|c|c|c|c|c|c|c|c|c|}
\hline \multirow{2}{*}{$\begin{array}{c}\text { Group } \\
\text { No. }\end{array}$} & \multirow{2}{*}{$\begin{array}{l}\text { Specimen } \\
\text { Label }\end{array}$} & \multirow{2}{*}{$\begin{array}{c}\text { Nominal } \\
\text { Coating } \\
\text { Thickness } \\
\text { (mils) }\end{array}$} & \multirow{2}{*}{$\begin{array}{l}\text { Norm. } \\
\text { stress } \\
\text { (ksi) }\end{array}$} & \multirow{2}{*}{$\begin{array}{l}\text { AASHTO } \\
\text { Stress } \\
\text { (ksi) }\end{array}$} & \multirow{2}{*}{$\begin{array}{c}\text { ACI } \\
\text { Stress } \\
(\mathrm{ksi})\end{array}$} & \multirow{2}{*}{$\begin{array}{c}\text { OJB } \\
\text { stress } \\
\text { (ksi) }\end{array}$} & \multicolumn{3}{|c|}{ Test/Prediction } \\
\hline & & & & & & & AASHTO & ACI & OJB \\
\hline \multicolumn{10}{|c|}{ 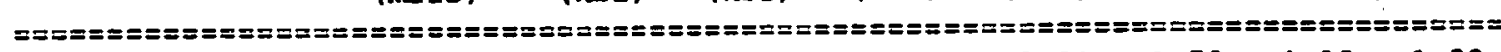 } \\
\hline \multirow[t]{3}{*}{1} & $5 N 0-12-0-U$ & 0.0 & 63.3 & 42.22 & 49.29 & 49.01 & 1.50 & 1.28 & 1.29 \\
\hline & $5 N 0-12-0-U$ & 0.0 & 66.2 & 42.22 & 49.29 & 49.01 & 1.57 & 1.34 & 1.35 \\
\hline & $5 N 0-12-0-C$ & 9.5 & 49.6 & 42.22 & 49.29 & 49.01 & 1.17 & 1.01 & 1.01 \\
\hline \multirow[t]{4}{*}{2} & $6 S 0-12-0-U$ & 0.0 & 43.8 & 29.74 & 34.73 & 39.51 & 1.47 & 7.26 & 1.11 \\
\hline & $6 s 0-12-0-c$ & 8.3 & 41.2 & 29.74 & 34.73 & 39.51 & 1.39 & 1.19 & 1.04 \\
\hline & $6 \mathrm{C} 0-12-0-\mathrm{U}$ & 0.0 & 49.2 & 29.74 & 34.73 & 39.51 & 1.65 & 1.42 & 1.25 \\
\hline & $6 \mathrm{C} 0-12-0-C$ & 8.8 & 37.6 & 29.74 & 34.73 & 39.51 & 1.26 & $1.0 \mathrm{~B}$ & 0.95 \\
\hline
\end{tabular}


Appendix D3 (continued)

\begin{tabular}{|c|c|c|c|c|c|c|c|c|c|}
\hline \multirow[t]{3}{*}{3} & $\begin{array}{l}8 S 0-16-0-U \\
8 S 0-16-0-C\end{array}$ & $\begin{array}{l}0.0 \\
9.4\end{array}$ & $\begin{array}{l}41.3 \\
37.2\end{array}$ & $\begin{array}{l}22.09 \\
22.09\end{array}$ & $\begin{array}{l}20.63 \\
20.63\end{array}$ & $\begin{array}{l}41.89 \\
41.89\end{array}$ & $\begin{array}{l}1.87 \\
1.68\end{array}$ & $\begin{array}{l}2.00 \\
1.80\end{array}$ & $\begin{array}{l}0.99 \\
0.89\end{array}$ \\
\hline & $8 N 0-16-0-U$ & 0.0 & 41.5 & 22.09 & 20.63 & 41.89 & 1.88 & 2.01 & 0.99 \\
\hline & $8 N 0-16-0-C$ & 9.5 & 35.7 & 22.09 & 20.63 & 41.89 & 1.62 & 1.73 & 0.85 \\
\hline \multirow[t]{4}{*}{ 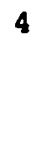 } & $11 S 0-24-0-U$ & 0.0 & 39.0 & 16.78 & 15.67 & 42.38 & 2.32 & 2.49 & 0.92 \\
\hline & $11 S 0-24-0-C$ & 9.3 & 28.1 & 16.78 & 15.67 & 42.38 & 1.67 & 1.79 & 0.66 \\
\hline & $11 C 0-24-0-U$ & 0.0 & 36.7 & 16.78 & 15.67 & 42.38 & 2.19 & 2.34 & 0.87 \\
\hline & $11 \mathrm{C} 0-24-0-\mathrm{C}$ & 10.3 & 30.1 & 16.78 & 15.67 & 42.38 & 1.79 & 1.92 & 0.71 \\
\hline
\end{tabular}

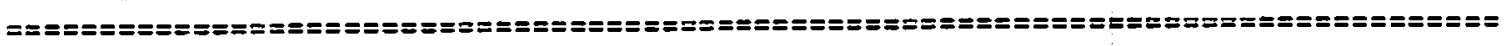

Hamad \& Jirsa (1990)

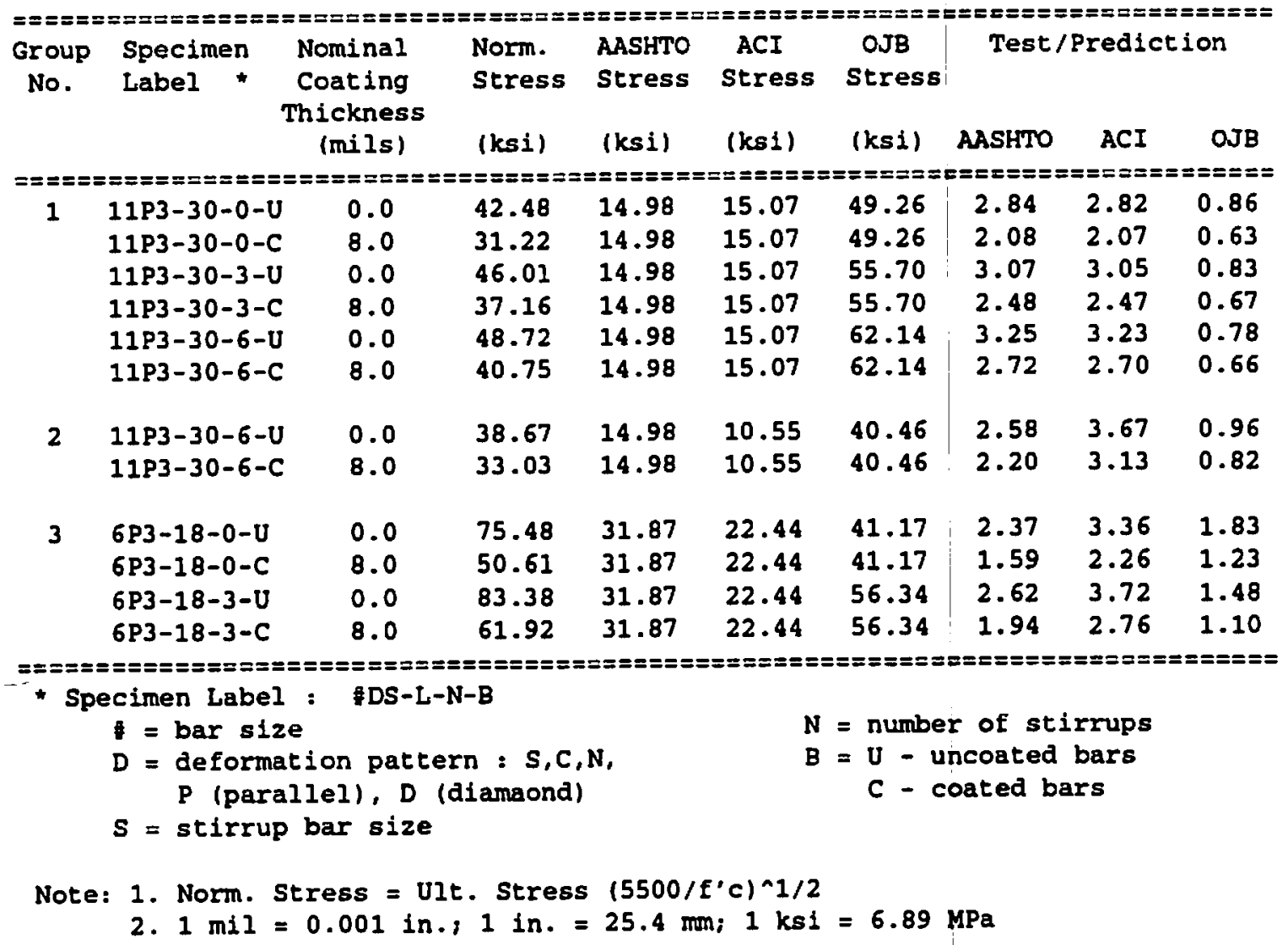

